OAK RIDGE

ORNL/TM-2012/226

NATIONAL LABORATORY

MANAGED BY UT-BATTELLE

FOR THE DEPARTMENT OF ENERGY

\title{
FHR Generic Design Criteria
}

\section{June 2012}

Prepared by

G. F. Flanagan

D. E. Holcomb

S. M. Cetiner

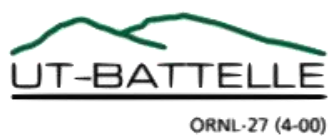




\section{DOCUMENT AVAILABILITY}

Reports produced after January 1, 1996, are generally available free via the U.S. Department of Energy (DOE) Information Bridge.

Web site http://www.osti.gov/bridge

Reports produced before January 1, 1996, may be purchased by members of the public from the following source.

National Technical Information Service

5285 Port Royal Road

Springfield, VA 22161

Telephone 703-605-6000 (1-800-553-6847)

TDD 703-487-4639

Fax 703-605-6900

E-mail info@ntis.gov

Web site http://www.ntis.gov/support/ordernowabout.htm

Reports are available to DOE employees, DOE contractors, Energy Technology Data Exchange (ETDE) representatives, and International Nuclear Information System (INIS) representatives from the following source.

Office of Scientific and Technical Information

P.O. Box 62

Oak Ridge, TN 37831

Telephone 865-576-8401

Fax 865-576-5728

E-mail reports@osti.gov

Web site http://www.osti.gov/contact.html

This report was prepared as an account of work sponsored by an agency of the United States Government. Neither the United States Government nor any agency thereof, nor any of their employees, makes any warranty, express or implied, or assumes any legal liability or responsibility for the accuracy, completeness, or usefulness of any information, apparatus, product, or process disclosed, or represents that its use would not infringe privately owned rights. Reference herein to any specific commercial product, process, or service by trade name, trademark, manufacturer, or otherwise, does not necessarily constitute or imply its endorsement, recommendation, or favoring by the United States Government or any agency thereof. The views and opinions of authors expressed herein do not necessarily state or reflect those of the United States Government or any agency thereof. 


\title{
FHR GENERIC DESIGN CRITERIA
}

\author{
G. F. Flanagan, D. E. Holcomb, and S. M. Cetiner
}

June 2012

Prepared by

OAK RIDGE NATIONAL LABORATORY

Oak Ridge, Tennessee 37831-6165

managed by

UT-BATTELLE, LLC

for the

U.S. DEPARTMENT OF ENERGY

under contract DE-AC05-00OR22725 



\section{CONTENTS}

Page

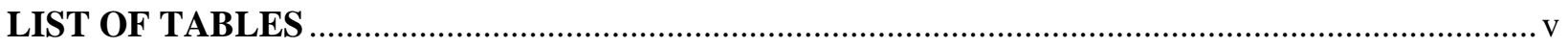

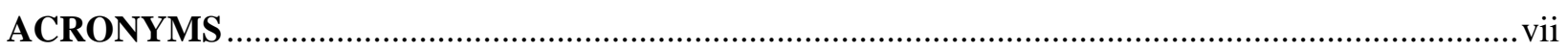

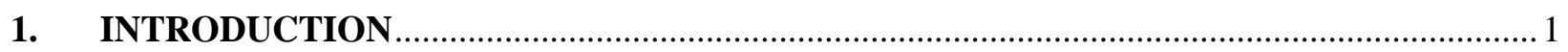

2. OVERVIEW OF FLUORIDE-SALT-COOLED HIGH-TEMPERATURE REACTORS ........ 1

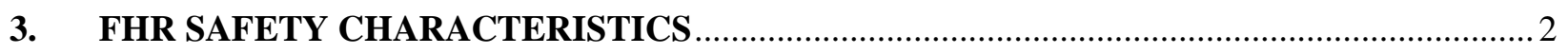

3.1 LARGE MARGIN TO FUEL FAILURE ...................................................................

3.2 MULTIPLE FISSION PRODUCT BARRIERS ............................................................. 2

3.3 MULTIPLE BARRIERS TO PREVENT UNCOVERING FUEL ….............................. 3

3.4 STRONG CORE NEGATIVE TEMPERATURE REACTIVITY FEEDBACK ................. 4

3.5 THERMALLY TRIGGERED NEGATIVE REACTIVITY FEEDBACK ........................ 4

3.6 SLOWLY EVOLVING ACCIDENTS ....................................................................... 4

3.7 PASSIVE, NATURAL CIRCULATION-BASED DECAY HEAT REJECTION ............... 4

3.8 LOW-CONSEQUENCE FUEL-HANDLING ACCIDENTS ........................................

3.9 STRUCTURALLY ROBUST FACILITIES TO WITHSTAND AIRCRAFT IMPACT

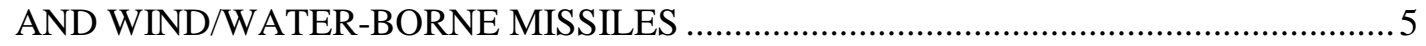

3.10 NONWATER-SOLUBLE USED FUEL ................................................................

3.11 LARGE SEPARATION BETWEEN NUCLEAR AND NON-NUCLEAR FACILITIES ...5

4. NUCLEAR POWER PLANT APPROVAL PROCESS-OVERVIEW AND OPTIONS......... 5

4.1 INTRODUCTION/BACKGROUND .......................................................................... 5

4.2 EXISTING NUCLEAR REACTOR LICENSING PROCESS ........................................... 6

4.3 NRC PROCESS FOR DETERMINATION OF COMPLIANCE WITH

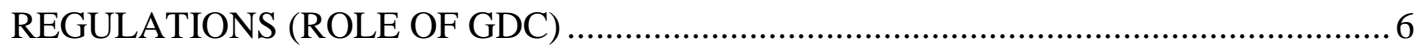

4.4 APPLICABILITY OF GDC TO RESEARCH AND TEST REACTORS ........................... 7

5. DEVELOPMENT OF GDCS FOR USE IN DESIGN, SAFETY, AND LICENSING OF

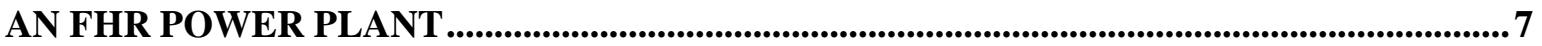

5.1 ACKNOWLEDGMENT OF GDC ADAPTATION ................................................... 7

5.2 APPLICABILITY OF THE CURRENT LICENSING PROCESS TO NON-LWR

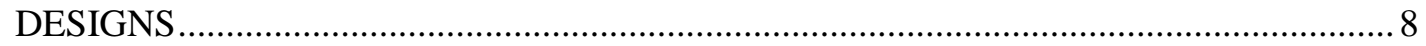

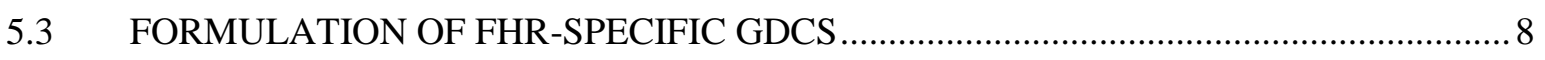

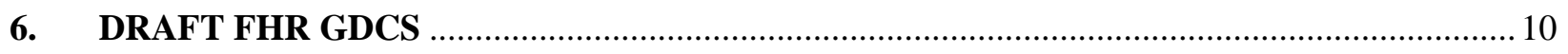

7. PATH FORWARD TOWARDS A SAFETY STANDARD AND FHR LICENSING ..............23

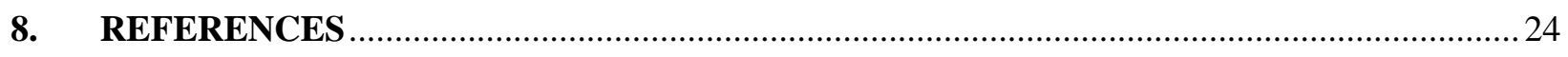

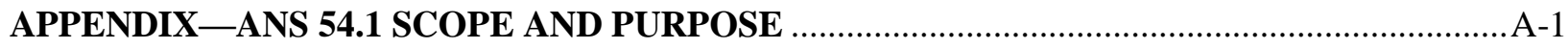





\section{LIST OF FIGURES}

Figure $\quad$ Page

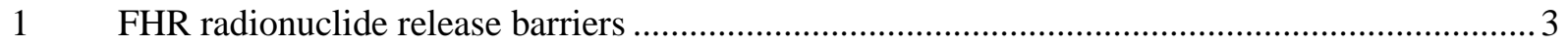

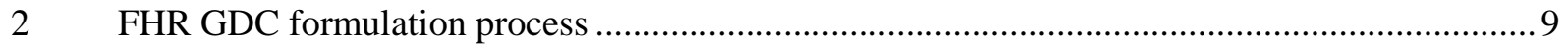

\section{LIST OF TABLES}

Table $\quad$ Page

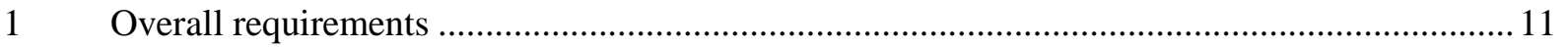

$2 \quad$ Protection by multiple fission product barriers.................................................................. 12

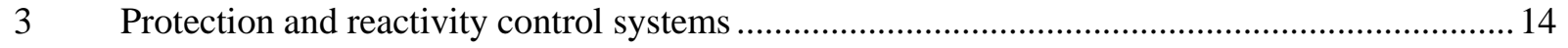

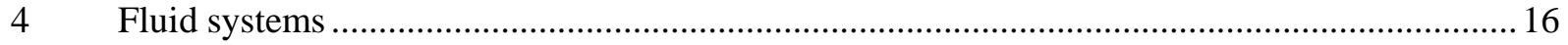

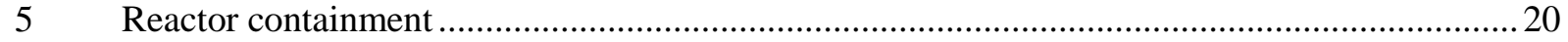

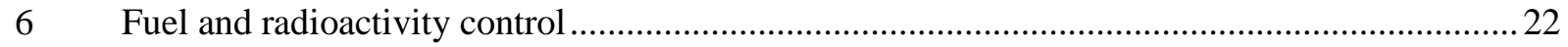





\section{ACRONYMS}

ACRS Advisory Committee on Reactor Safeguards

AHTR advanced high-temperature reactor

ATWS anticipated transient without scram

BARC Bombay Atomic Research Center

CRBR Clinch River Breeder Reactor

DOD U.S. Department of Defense

DOE U.S. Department of Energy

DRACS direct reactor auxiliary cooling system

FHR Fluoride-Salt-Cooled $\underline{H i g h-T e m p e r a t u r e ~ R e a c t o r ~}$

GDC General Design Criteria

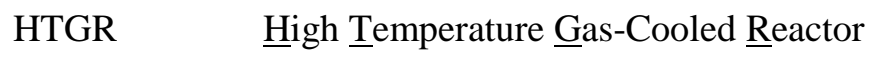

IAEA International Atomic Energy Agency

LMR liquid-metal reactor

LWR light-water reactor

MIT Massachusetts Institute of Technology

NRC U.S. Nuclear Regulatory Commission

ORNL Oak Ridge National Laboratory

PIRT Phenomenon Identification and Ranking Table

PRA Probabilistic Risk Assessment

RMTF Risk Management Task Force

SAFR sodium advanced fast reactor

SAR Safety Analysis Report

SER Safety Evaluation Report

SFR sodium fast reactor

SmAHTR Small modular Advanced High-Temperature Reactor

SME subject matter expert

SRP Standard Review Plan

SSC systems, structures, and components 



\section{INTRODUCTION}

The purpose of this document is to provide an initial, focused reference to the safety characteristics of

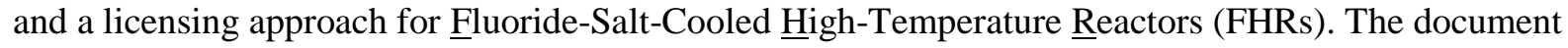
does not contain details of particular reactor designs nor does it attempt to identify or classify either design basis or beyond design basis accidents. Further, this document is an initial attempt by a small set of subject matter experts to document the safety and licensing characteristics of FHRs for a larger audience. The document is intended to help in setting the safety and licensing research, development, and demonstration path forward. Input from a wider audience, further technical developments, and additional study will be required to develop a consensus position on the safety and licensing characteristics of FHRs.

This document begins with a brief overview of the attributes of FHRs and then a general description of their anticipated safety performance. Following this, an overview of the US nuclear power plant approval process is provided that includes both test and power reactors, as well as the role of safety standards in the approval process. The document next describes a General Design Criteria (GDC)-based approach to licensing an FHR and provides an initial draft set of FHR GDCs. The document concludes with a description of a path forward toward developing an FHR safety standard that can support both a test and power reactor licensing process.

\section{OVERVIEW OF FLUORIDE-SALT-COOLED HIGH-TEMPERATURE REACTORS}

FHRs are a class of reactor that, by definition, feature low-pressure liquid fluoride salt cooling, coated-particle fuel, and fully passive decay heat rejection. As high-temperature plants, FHRs can support either electricity generation or process heat production. FHRs, in principle, have the potential to be low-cost power producers while maintaining full passive safety. However, no FHR has been built, and no FHR design has reached the stage of maturity where realistic, detailed economic analysis can be performed.

While FHRs represent a distinct reactor class, they inherit desirable attributes from other thermal power plants whose characteristics can be studied to provide general guidance on plant configuration, anticipated performance, and costs. The extensive US molten salt reactor development program from the 1950s-1970s provides experience on the materials, procedures, and components necessary to use liquid fluoride salts. Liquid-metal reactors provide design experience on using low-pressure liquid coolants, passive decay heat removal, and hot refueling. High-temperature gas-cooled reactors (HTGRs) provide experience with coated-particle fuel and graphite components. Light-water reactors (LWRs) show the advantages of transparent, high-heat-capacity coolants with low chemical reactivity. Modern coal-fired power plants provide design experience with advanced supercritical-water power cycles, and natural gas turbines provide experience with Brayton power cycles.

Several different FHRs are currently under design by different organizations. Oak Ridge National Laboratory (ORNL) is leading the preconceptual design of the Advanced High Temperature Reactor (AHTR), which is a large [1500 MW(e)] central station-type power plant focused on low-cost electricity production. The Massachusetts Institute of Technology (MIT) is leading the efforts toward developing a preconceptual design for a $<20 \mathrm{MW}(\mathrm{t})$ test reactor. The Shanghai Institute of Technology is leading a design effort to develop the first FHR critical facility/test reactor [2 MW(t)]. The University of California at Berkeley is developing a preconceptual design for a mid-sized [410 MW(e)] initial commercial prototype reactor. ORNL is also developing a preconceptual design of a Small modular Advanced HighTemperature Reactor [SmAHTR; $125 \mathrm{MW}(\mathrm{t})$ ] focused on thermal power production. The Bombay Atomic Research Center (BARC) is developing an FHR focused on hydrogen production. Finally, the 
Georgia Institute of Technology has recently begun investigation of a higher fuel density core variant of an FHR. The design efforts in the United States are all under the sponsorship of the Department of Energy.

\section{FHR SAFETY CHARACTERISTICS}

FHRs feature full passive safety and thus do not require any system or operator active response to avoid core damage or large off-site release of radioactive material for any design basis accident or lowfrequency beyond design basis accident, including severe earthquakes, tsunamis, large commercial plane impact, or permanent station blackout. The safety characteristics of FHRs arise from fundamental physics as well as well-designed, constructed, and maintained systems, structures, and components (SSCs). The AHTR has the most mature mechanical/structural design of any of the FHR reactors under consideration. Thus, the safety/design characteristics presented in this document are more directly reflective of the AHTR than other designs. This section provides a conceptual summary of each of the FHR safetyrelevant characteristics, in turn, as background input to developing FHR-specific GDCs.

\subsection{LARGE MARGIN TO FUEL FAILURE}

As the current advanced gas reactor fuel R\&D program ${ }^{1}$ as well as prior International Atomic Energy Agency (IAEA) HTGR fuel demonstration programs ${ }^{2}$ have shown, the silicon carbide barrier layer within coated-particle fuel in properly fabricated coated-particle fuel will remain intact several hundred degrees above the fuel operating temperature, retaining nearly all of the fission fragments. The primary coolant does not boil until it reaches temperatures over $1400^{\circ} \mathrm{C}$, and the current maximum design operating temperature is $700^{\circ} \mathrm{C}$. Additionally, the viscosity of fluoride salt coolants decrease with increasing temperatures, resulting in increased coolant flow to the hottest fuel, thereby reducing fuel hot spots. Further, while the power density of FHR cores is well above that of HTGRs, they contain larger numbers of fuel particles, resulting in low average particle power $(41 \mathrm{~mW} /$ particle in the AHTR) and limiting the radiochemical challenge to the silicon carbide containment layer within the fuel.

\subsection{MULTIPLE FISSION PRODUCT BARRIERS}

The AHTR features four separate containment layers, as illustrated in Fig. 1. The innermost layer is the silicon carbide layer within the coated-particle fuel. The second layer is the primary circuit and upper gas region containment shell. The third containment layer is the argon-gas-filled, low-pressure containment structure within the reactor building. The outermost containment layer is the steel-lined trench surrounding the reactor building combined with a flexible upper seal structure (intended to prevent flooding of the seismic isolation trench). 


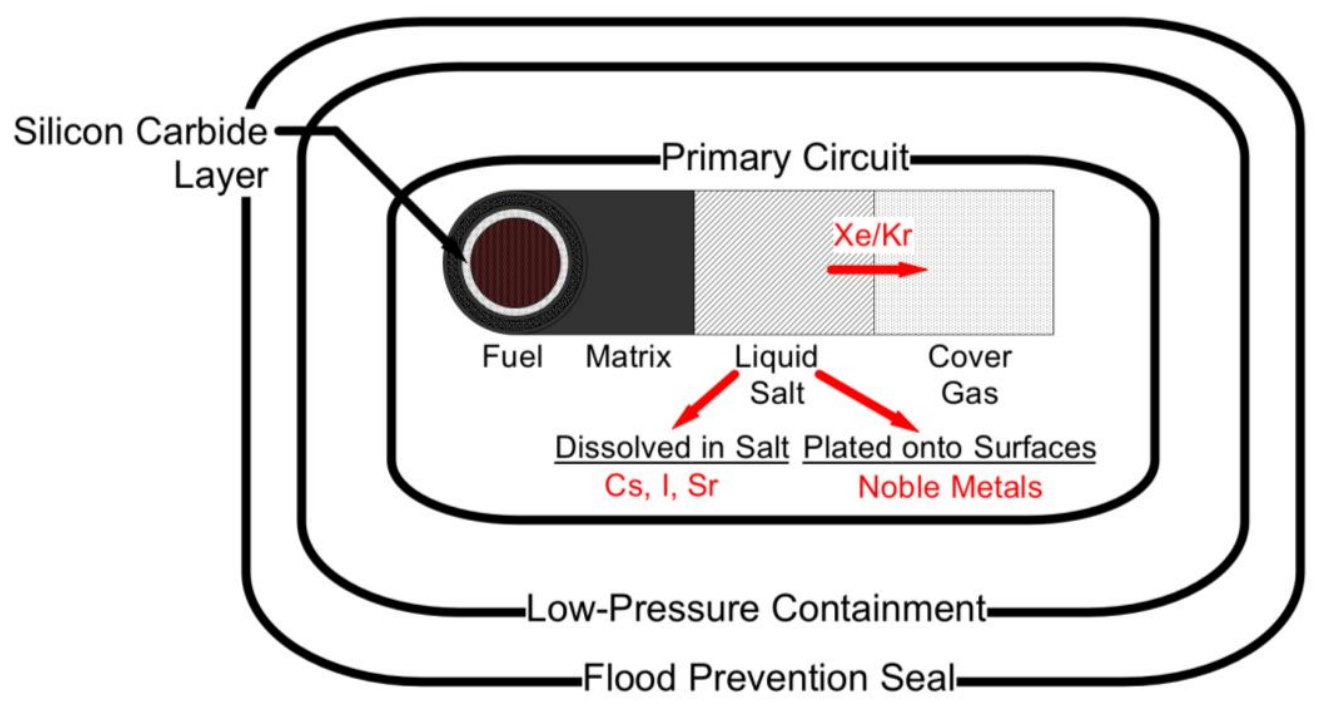

Fig. 1. FHR radionuclide release barriers.

In the case of a failed silicon carbide containment layer, the emerging radionuclides will be trapped on the carbon surfaces within the core, dissolve into the liquid salt, and/or be confined by the next reactor containment layer. The noble gases will largely escape from the top surface of the salt and be trapped by the upper level gas containment shell. The upper gas containment shell is sealed to the top flange of the reactor vessel to provide a second level of containment during operation. The upper containment shell envelops the control element drive mechanisms (located on the upper vessel flange) and provides closed end guide thimbles for the control blade leader rods and guide tubes when retracted outside of the vessel. Note that the reactor vessel itself does not form a gas-tight containment in that the upper head penetrations are only loose fitting. In addition to serving as a radionuclide containment, the upper layer seal provides an initial tritium and beryllium contamination barrier.

All of the non-noble gas fission products have been shown by experience with molten salt reactors to be well retained within the salt (the noble metals tend to plate out on surfaces or form suspended colloids), reducing the available radionuclide source term. The reactor vessel and primary piping are located within a low-pressure, low-leakage, inert atmosphere containment building below grade, providing a third fission product barrier. The steel-lined trench that surrounds the reactor building as part of the seismic protection system also has a flexible liquid and vapor impermeable seal at its top to avoid flooding accidents and, thus, provides a fourth fission product barrier.

The primary-to-intermediate loop heat exchanger is located at the low point of the intermediate loop, resulting in a higher pressure on the intermediate coolant side of the heat exchanger. Thus, tube ruptures in the primary-to-intermediate heat exchanger would results in inward leakage of intermediate coolant rather than outward leakage of potentially contaminated primary coolant. The intermediate loop is not a significant radionuclide escape route due to the pressure differential between the loops. The inward leakage rationale also applies to the primary to direct reactor auxiliary cooling system (DRACS) heat exchangers due to the elevation of the DRACS loops.

\subsection{MULTIPLE BARRIERS TO PREVENT UNCOVERING FUEL}

The reactor vessel does not include any penetrations below $\sim 20 \mathrm{~cm}$ above the top of the DRACS heat exchangers. Fluoride salts have high volumetric heat capacity, and a large volume of salt is maintained over the core during both operations and refueling, providing a substantial thermal margin. FHRs include 
a guard vessel so that in the event of primary vessel failure the core will remain covered with salt. Further, due to the high melting point of the primary salt coolant, small leaks are expected to self-seal as the coolant freezes upon leaking. While the fuel is buoyant in the coolant, multiple upper core support structures including the upper core support plate, the weight of the control blade, and the control blade guide tube all maintain the fuel below the surface of the coolant in the case of the AHTR.

\subsection{STRONG CORE NEGATIVE TEMPERATURE REACTIVITY FEEDBACK}

The negative fuel temperature coefficient due to Doppler broadening is roughly 80 times as large as that of LWRs. The reactor leakage feedback coefficient is also negative. The coolant temperature coefficient can be either positive or negative depending on the carbon-to-heavy metal ratio within the core. However, completely voiding the core of coolant would not result in prompt criticality (but could result in massive fuel damage due to lack of heat transfer). Carbon-to-heavy metal ratios with near-zero (or potentially slightly positive) coolant density feedbacks can result in higher achievable fuel burnup and, thus, a more economic fuel cycle. Note that voiding an FHR core (and thus potentially inserting a small positive reactivity) is also technically difficult (due to boiling, draining, or gas bubble entrainment in the coolant). The coolant has several hundred degrees of margin to boiling. In the case of external loop reactors, all of the loops include anti-siphon valves that remove any bubbles entrained in the flow, and the reactor vessel has no penetrations below $\sim 20 \mathrm{~cm}$ above the top of the DRACS heat exchangers.

\subsection{THERMALLY TRIGGERED NEGATIVE REACTIVITY FEEDBACK}

The ability of the core and coolant to tolerate temperature rises enables the use of thermal triggers to provide negative reactivity feedback. The control blades can employ thermal fuses (melt point alloys) that would passively release the blades in the event of an over-temperature accident. A secondary shutdown poison salt can be released into the core inlet plenum in the event of excessive temperature through the use of a poison salt accumulator with a melt point alloy used as the braze to seal its lid. The use of multiple passive negative reactivity insertion mechanisms is intended to make anticipated transient without scream (ATWS) accidents incredible.

\subsection{SLOWLY EVOLVING ACCIDENTS}

FHRs have much lower power density cores than LWRs $\left(<20 \mathrm{MW} / \mathrm{m}^{3}\right.$ versus $\left.\sim 110 \mathrm{MW} / \mathrm{m}^{3}\right)$, albeit with higher power densities than HTGRs, providing for longer times for the reactor systems to respond to upset conditions. Further, the large volume of salt (volumetric heat capacity of FLiBe is $4670 \mathrm{~kJ} / \mathrm{m}^{3}-\mathrm{K}$ at $700^{\circ} \mathrm{C}$ ) and graphite in the reactor vessel provides for substantial local thermal storage to provide time for recovery operations. In the case of the AHTR, the reactor vessel includes $\sim 9 \mathrm{~m}$ of salt depth above the core with a reactor vessel diameter slightly over $10 \mathrm{~m}$.

\subsection{PASSIVE, NATURAL CIRCULATION-BASED DECAY HEAT REJECTION}

Fluoride salts have large coefficients of thermal expansion that combine with their large volumetric heat capacities that allow design for excellent natural circulation cooling. The natural circulation cooling enables the use of DRACS-type decay heat rejection to the local air. Similar natural-circulation-driven emergency heat rejection is also possible for the used fuel storage pool. The DRACS systems are modular and independent, enabling the system to continue to function following the failure of individual units. The AHTR design calls for three independent DRACS systems and is intended to withstand design basis accidents with only two out of three systems in operation. Sufficient decay heat rejection is provided to avoid vessel failure in the event of complete, permanent station blackout and the loss of a single full DRACS cooling system. Additionally, while not safety grade, a maintenance cooling system is provided that is independent of the primary heat rejection system. 


\subsection{LOW-CONSEQUENCE FUEL-HANDLING ACCIDENTS}

The AHTR fuel assemblies are slightly buoyant. Each fuel assembly includes a molybdenum alloy control blade to provide sufficient ballast to sink the fuel in the event of its being dropped during movement. Liquid fluoride salts are transparent, enabling visual guidance to the fuel movement, thus substantially reducing the risk of unanticipated mechanical impacts while enabling visual confirmation of mechanical gripper actions. Since each fuel assembly has a control blade, dropping the fuel cannot result in a criticality accident. Further, as the fuel only sinks slowly in the coolant it would not mechanically damage itself or any other reactor structures as a result of being dropped. Also, the upper fuel assembly structures provide for separated flow paths for each assembly, avoiding the possibility for blocking the exit flow paths due to a fuel assembly falling across the top of the core.

\subsection{STRUCTURALLY ROBUST FACILITIES TO WITHSTAND AIRCRAFT IMPACT AND WIND/WATER-BORNE MISSILES}

FHR reactor buildings and used fuel storage pools are intended to be located below grade, providing shielding from aircraft impact and wind/water-borne missiles.

\subsection{NONWATER-SOLUBLE USED FUEL}

Carbon-enveloped coated-particle fuel is not water soluble, enabling used fuel assembly emplacement in shallow $(<1 \mathrm{~km})$ dry wells for eventual (after 6-12 months in a containment used fuel pool) local intermediate-term retrievable storage with very low probability for radionuclide escape into the surrounding environment. The first layer of containment remains with the fuel after it is unloaded from the core, and the silicon carbide containment layer is not anticipated to fail in the more benign used fuel storage environment. The envisioned local used fuel storage dry wells (boreholes) closely resemble cased and cemented petroleum wells, which can effectively reject decay heat to the surrounding rock due to their large surface-to-volume ratio.

\subsection{LARGE SEPARATION BETWEEN NUCLEAR AND NON-NUCLEAR FACILITIES}

As high-temperature plants, FHRs can support either high-efficiency electricity generation or industrial process heat production. The low-pressure liquid-salt intermediate loop of an FHR enables separating, by several tens of meters, the reactor building from the energy use processes with their potential for adverse mechanical or chemical impacts on the nuclear island. The reactor is also separated from the pressure waves propagating down the intermediate loop piping by rupture disks or other pressure relief mechanisms such that it is not credible for a disturbance within the energy use portion of the plant to propagate to the nuclear island.

\section{NUCLEAR POWER PLANT APPROVAL PROCESS—OVERVIEW AND OPTIONS}

\subsection{INTRODUCTION/BACKGROUND}

The Atomic Energy Act of 1954 and other applicable laws, in particular the Energy Reorganization Act of 1974, establish the fundamental basis by which the US Nuclear Regulatory Commission (NRC) regulates the civilian uses of nuclear materials.

The NRC has developed regulations that limit radiation exposure to workers and the public by requiring its licensees to limit the time persons are exposed to radiation, limit access to areas containing radioactive materials, and provide physical barriers between radioactive materials and individuals. These 
controls are associated with (1) requirements for radioactive materials to be contained within devices or facilities to prevent their inadvertent release and (2) measures to address the possible degradation of barriers and controls intended to protect workers and the public. NRC rules and programs also address, to varying levels of specificity, the need for personnel to be trained and qualified for the tasks they perform.

The risk environment for reactors focuses predominantly on the prevention and mitigation of lowfrequency, high-consequence events, whereas the risk environment for materials uses focuses primarily on high-frequency, low-consequence events. The consideration of risks and tailoring regulations and oversight to manage those risks is inherent in current NRC programs although not always explicitly defined. Thus, NRC imposes risk management principles as part of the regulatory process. ${ }^{3}$

\subsection{EXISTING NUCLEAR REACTOR LICENSING PROCESS}

The NRC has developed a process for licensing a nuclear power reactor or research/test reactors based upon paragraph 103 or paragraph 104, respectively, of the Atomic Energy Act of 1954 and its amendments and the Energy Reorganization Act of 1974. The legal requirements are principally imbedded in two sets of reactor-focused regulations - 10CFR50 "Domestic Licensing of Production and Utilization Facilities," which has been the basis for all the power and research/test reactors in operation today [with the exception of Department of Energy (DOE) or Department of Defense (DOD)-owned facilities], and 10CFR52 "Licenses, Certifications, and Approvals for Nuclear Power Plants," which has been used for the Generation III and III+ reactor licensing process since 1997. The 10CFR52 does not apply to research or test reactors (paragraph 104 licenses). The 10CFR20 "Standards for Protection Against Radiation" applies to all reactors.

10CFR50 involves a two-step licensing process in which a construction permit is obtained followed by an operating license after the plant is constructed. The regulations associated with 10CFR50 are generally deterministic in nature and, in some areas, are prescriptive in their application. The 10CFR50 licensing process allows for concurrent reactor construction and license application review. The 10CFR52 process certifies a design for use by an applicant by rulemaking. The applicant can then reference the certified design to obtain a combined construction permit and operating license prior to starting construction. The 10CFR52 process recognizes the usefulness of risk-informed and performance-based approaches and, thus, requires the applicant to have a plant-specific probabilistic risk assessment (PRA) for their reactor. However, part 52 still requires the applicant to address a prescriptive set of design basis accidents as well as most of the requirements contained in part 50.

\subsection{NRC PROCESS FOR DETERMINATION OF COMPLIANCE WITH REGULATIONS (ROLE OF GDC)}

In either process (Part 50 or Part 52), the nuclear power reactor applicant must provide the principal design criteria for the reactor along with many other requirements. The principal design criteria establish the necessary design, fabrication, construction, testing, and performance requirement for SSCs that provide reasonable assurance that the facility can be operated without undue risk to the health and safety of the public. The minimum requirements for principal design criteria are contained in Appendix A of 10CFR 50 and are referred to as GDC. The GDC are written to provide the minimal design criteria requirements for LWRs similar in design and locations to plants for which construction permits have been issue by the NRC. The introduction to Appendix A further states that the GDC are considered to be generally applicable to other types of reactors and are intended to provide guidance in establishing the principal design criteria for such other types of reactors.

The NRC staff must make a determination as to whether a reactor design ensures adequate protection of public health and safety and to be in accordance with the common defense and security. In order for NRC to make the judgment of "adequate protection," the staff reviews the applicant's Safety Analysis Report (SAR), among many other documents. The SAR indicates how the principal design criteria are 
specifically implemented in the applicant's reactor design and operation. In doing the review, the NRC has established a Standard Review Plan (SRP) ${ }^{4}$ that guides the review process by comparing the design against the regulatory requirements. Conformance with the SRP is not a regulatory requirement, but it references the requirements as acceptance criteria. The GDC and a few specific regulations are cited as the acceptance criteria in each section of the SRP.

The Safety Evaluation Report is prepared by the NRC staff, which provides the justification that the reactor's principal design criteria meet the adequate protection requirement as determined by the staff review. In this document the acceptance criteria (the GDC) are discussed along with the explanation as to how the staff evaluated the design against the GDC and made their determination of adequate protection. Thus, the GDC are not only requirements but have become the acceptance criteria imbedded in the safety analysis review process.

\subsection{APPLICABILITY OF GDC TO RESEARCH AND TEST REACTORS}

Research and test reactors are governed by the 10CFR50 regulations for the most part, but the interpretations are tailored to be commensurate with radioactive inventory available pursuant to the Atomic Energy Act provisions of paragraph 104, indicating these facilities should be regulated to the minimum extent consistent with protection of the health and safety of the public. Thus, the GDC have been replaced with more qualitative acceptance criteria. These constitute the minimal design criteria for use in addressing the design criteria for this type reactor. For research and test reactors, the acceptance criteria are found in NUREG 1537, Guidelines for Preparing and Reviewing Applications for Licensing of Non-Power Reactors. These acceptance criteria, while less specific than the GDC found in Appendix A of 10CFR50, are LWR focused. Modification will be needed to allow use of these acceptance criteria in the review of an FHR research and test reactor.

\section{DEVELOPMENT OF GDCS FOR USE IN DESIGN, SAFETY, AND LICENSING OF AN FHR POWER PLANT}

\subsection{ACKNOWLEDGMENT OF GDC ADAPTATION}

In the introduction to Appendix A of 10CFR50, "General Design Requirements for Nuclear Power Plants," a number of important caveats are mentioned which indicate that the authors understand the set of GDC are not static. It states "The development of the General Design Criteria is not yet complete" in which several examples pertaining to LWRs are provided. It further states "Thus, some of the specific design requirements for structures, systems and components important to safety have not as yet been suitably defined." It further indicates that updates may be required as new requirements and features are introduced. "In particular, it is expected that additional or different criteria will be needed to take into account unusual sites and environmental conditions, and for water-cooled nuclear power units of advanced design."

In addition to caveats related to completeness, the introduction specifically allows room for departure from the GDC. "Also, there may be water-cooled nuclear power units for which fulfillment of some of the General Design Criteria may not be necessary or appropriate. For plants such as these, departure from the General Design Criteria must be identified and justified." 


\subsection{APPLICABILITY OF THE CURRENT LICENSING PROCESS TO NON-LWR DESIGNS}

Because the GDC and the design basis accidents that are derived from the GDCs are specific to LWRs, the issue of creating a technology neutral risk-informed and performance-based approach to meeting the regulatory requirements was recently examined by the NRC.

At the direction of the Commission, the NRC staff proposed a process of making the licensing process technology neutral to allow any type of reactor to be licensed based on the risk profile associated with the design. The results were published as NUREG-1860, Feasibility Study for a Risk-Informed and Performance-Based Regulatory Structure for Future Plant Licensing. ${ }^{5}$ This document was reviewed by the Advisory Committee on Reactor Safeguards (ACRS) and the NRC Commission. Many questions were raised by the suggested approach during the review process. The Commission recommended to publish the NUREG but to defer adaption of the framework until it could be determined by test application that an equivalent level of safety could be secured using such a framework and that it represented a more efficient approach to licensing non-LWRs. It was suggested that the test application be done on the DOE New Generation Nuclear Plant (a high-temperature gas reactor). The recent Risk Management Task Force (RMTF) report, NUREG 2150, ${ }^{3}$ stated "This approach (NUREG 1860) was judged to require a significant revision of the basic framework used for the licensing and oversight of a particular type of NRC-regulated activity."

The RMTF makes the following recommendation regarding Generation IV type reactors: "the RMTF recommends that the concept of design basis accidents be maintained, but the NRC should be amenable to and promote, where practical, the adoption of more risk-informed approaches for the selection of relevant scenarios (e.g., alternatives to the single failure criterion) for design basis accidents."

Mayfield (Division Director of Advanced Reactors at NRC) in a recent discussion related to Licensing of New Reactors states that "While there is clear interest in making better use of risk analysis and risk insights in the regulatory process, and in making changes in the regulatory infrastructure to accommodate technologies beyond light-water reactors, it is important to note that the basic regulatory and technical structure in Part 50 and Part 52 can be applied to other technologies. For example, gascooled reactors were licensed in the past (Peach Bottom 1 and Fort St. Vrain) and, more recently, the staff reviewed and prepared a safety evaluation of a sodium fast reactor (PRISM)."

Based on the above NRC studies and statements, it was decided that a for the purposes of safety and licensing of the FHR, the approach should closely adapt the current LWR-based process except where differences are mandated by unique features of the FHR design. The first step in this process was to create a set of GDCs for FHRs.

\subsection{FORMULATION OF FHR-SPECIFIC GDCS}

Since the regulations as described in Section 5.1 acknowledge that the GDC may be revised for some LWR designs, we have approached this process by expanding the acknowledgment to include non-LWR types of nuclear power plants. In doing so it was decided to keep a one-to-one correspondence to the GDC as listed in Appendix A. Furthermore, the intent of the GDC was preserved, if applicable, to an FHR even though the LWR prescriptive features contained in the current GDC wording may need to change because of the reactor characteristics. This process closely follows the approach used for the PRISM and SAFR reactors as referred to by Mayfield in Section 5.2. By starting with the existing LWR GDC as a base, and keeping the one-to-one correspondence and intent, the process allows the existing design review process, which uses the GDCs, to be applied to an FHR with very little revision.

A review of each GDC was conducted to determine if (1) the GDC could be used without change, (2) minor wording changes were needed (such as removal of PWR or BWR language), (3) significant changes to the content of the GDC such as imbedded acceptance criteria needed to be changed, (4) the GDC is not applicable to an FHR, or (5) the FHR design warrants a new GDC because of its unique 
aspects. In conducting this review process of evaluating the current LWR-focused GDCs for applicability to an FHR, 13 GDC required no changes, 13 GDC required only minor wording changes, 22 required technically significant changes, and 7 were found not to be applicable. Only one new GDC was determined to be needed. The new GDC pertains to ATWS and is similar to the ATWS GDC proposed in ANS 54.1. ${ }^{6}$ The principal design issue that required significant changes in the FHR GDC was associated with the robust nature of the fuel particles. In the case of LWRs and SFRs, the principal barrier to prevent fission product release is damage to the cladding. In most accidents in these reactors, this is the barrier that is challenged first during the accident. In the case of an FHR, the principal barrier to fission product release is not direct failure of the fuel particles, which is not challenged in most events, but instead is failure of the reactor vessel or other structures that serve as the primary coolant boundary. This acceptance criterion was used in lieu of preventing cladding failure in the FHR GDC. The process employed for generating the FHR-specific set of GDCs is illustrated in Fig. 2.

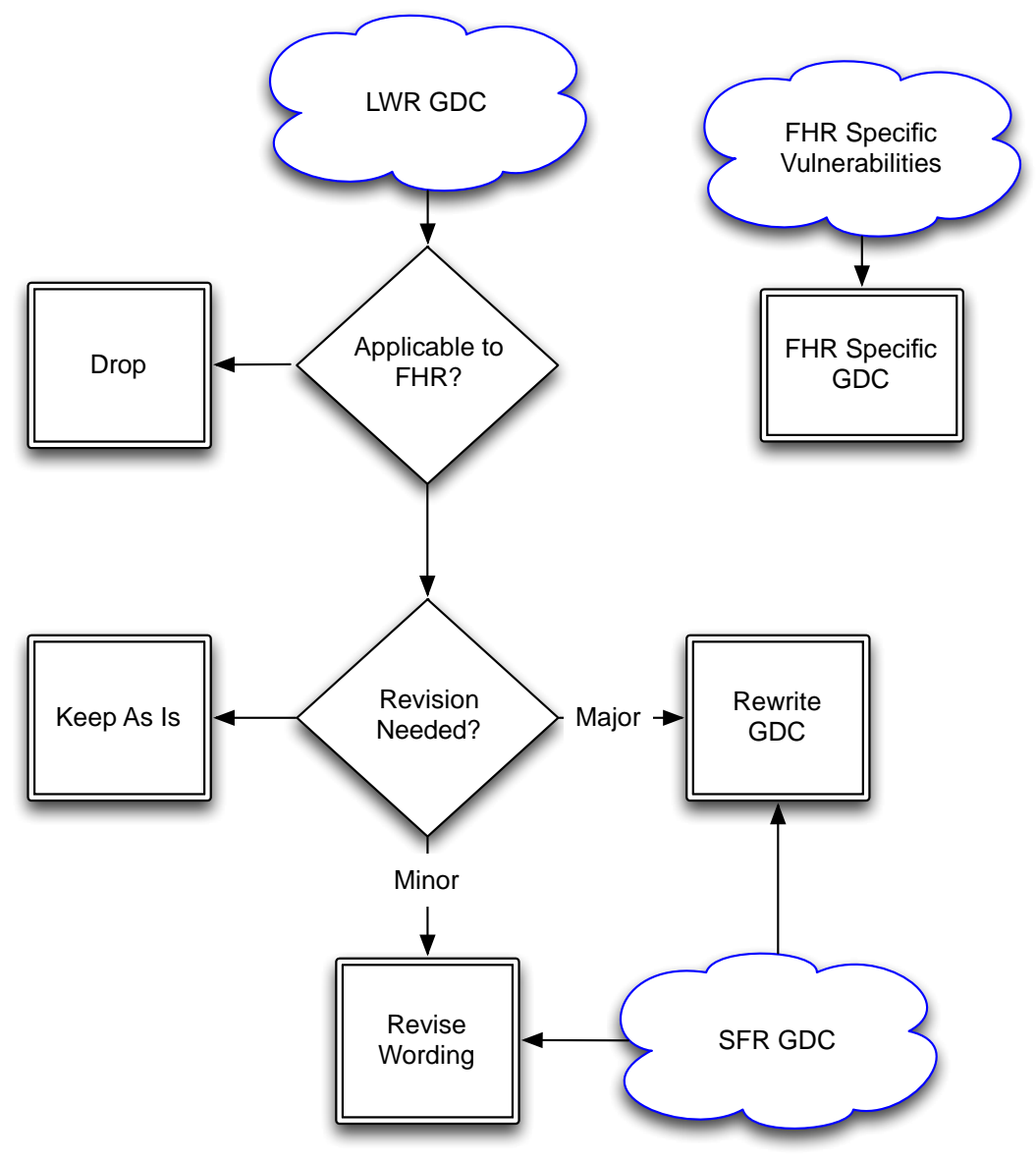

Fig. 2. FHR GDC formulation process.

The approach of rewriting the GDC based on the unique features of a non-LWR design is not new. This approach was used by the liquid-metal reactor (LMR) designers during the licensing of the Clinch River Breeder Reactor (CRBR) and review of the PRISM and SAFR designs. After the LMR GDCs were constructed and agreed to by the NRC, the new GDCs were codified in an ANS standard (ANS 54.1) so they could be used by subsequent LMR design organizations. This standard is being updated to incorporate risk-informed processes for selection of Licensing Bases Events and classification of SSCs but still retains the deterministic GDC created for LMRs in the earlier version of the standard. 
A similar approach was used for the licensing of the Fort St. Vrain HTGR referred to in Section 5.2. The NGNP (another high-temperature gas reactor) has deviated from this deterministic approach of customizing existing GDCs to the specific reactor class under consideration in that its designers have reformulated a set of high-level safety criteria for the HTGR and applied a technology neutral framework similar to that proposed for NUREG- $1860 .^{7}$ This approach is under review by the NRC.

\section{DRAFT FHR GDCS}

The proposed FHR GDCs maintain the same topical structure as the current LWR-focused set:

1. Overall Requirements

2. Protection by Multiple Fission Product Barriers

3. Protection and Reactivity Control Systems

4. Fluid Systems

5. Reactor Containment

6. Fuel and Radioactivity Control

The original LWR and proposed FHR GDCs are presented with one table for each topic area for ease of comparison. Added words to the FHR standard are shown in blue and removed words are shown in red with a strike-though line. A description of the modification basis is also provided.

The phrase "important to safety" found in the LWR GDC was replaced by "safety related" in the FHR GDC. This was in keeping with the process used in the LMR ANS standard (ANS 54.1). The rationale is that the regulations have no specific definition for "important to safety" except as it relates to electrical systems. The lack of a definition for "important to safety" could lead to ambiguity in interpreting the applicability of the GDC. The term "safety related" has a specific definition given in the 10CFR50.2 and was therefore used in the FHR GDC. Note this ambiguity is discussed in Generic Letter 84-01 (NRC Use of Terms "Important to Safety" and "Safety Related") and in in a letter from the Utility Safety Classification Group to William Dircks (NRC) dated August 23, 1983.

As the draft ANS liquid-metal safety/design standard (ANS 54.1) was used as a template for modifying the existing LWR GDCs, the scope and purpose sections of this standard are included as an appendix to this document. ANS 54.1 specifies four foci within its scope (1) define reactor safety objectives, (2) specify general design criteria, (3) select licensing basis events, and (4) classify of SSCs in response to licensing basis events. The following tables are intended to serve as a starting point for specifying general design criteria as a starting point for developing an equivalent standard for FHRs. 
Table 1. Overall requirements

\begin{tabular}{|c|c|c|}
\hline No. & Proposed FHR GDC & $\begin{array}{l}\text { Modification } \\
\text { basis }\end{array}$ \\
\hline 1.1 & $\begin{array}{l}\text { Quality Standards and Records } \\
\text { Safety-related structures, systems, and components important to safety shall be designed, } \\
\text { fabricated, erected, and tested to quality standards commensurate with the importance of the safety } \\
\text { functions to be performed. Where generally recognized codes and standards are used, they shall be } \\
\text { identified and evaluated to determine their applicability, adequacy, and sufficiency, and shall be } \\
\text { supplemented or modified as necessary to assure a quality product in keeping with the required } \\
\text { safety function. A quality assurance program shall be established and implemented in order to } \\
\text { provide adequate assurance that these structures, systems, and components will satisfactorily } \\
\text { perform their safety functions. Appropriate records of the design, fabrication, erection, and testing } \\
\text { of structures, systems, and components important to safety shall be maintained by or under the } \\
\text { control of the nuclear power unit licensee throughout the life of the unit. }\end{array}$ & $\begin{array}{l}\text { Language } \\
\text { update }\end{array}$ \\
\hline 1.2 & $\begin{array}{l}\text { Design Bases for Protection Against Natural Phenomena } \\
\text { Safety-related structures, systems, and components important to safety shall be designed to } \\
\text { withstand the effects of natural phenomena such as earthquakes, tornadoes, hurricanes, floods, } \\
\text { tsunami, and seiches without loss of capability to perform their safety functions. The design bases } \\
\text { for these structures, systems, and components shall reflect: (1) Appropriate consideration of the } \\
\text { most severe of the natural phenomena that have been historically reported for the site and } \\
\text { surrounding area, with sufficient margin for the limited accuracy, quantity, and period of time in } \\
\text { which the historical data have been accumulated, (2) appropriate combinations of the effects of } \\
\text { normal and accident conditions with the effects of the natural phenomena, and (3) the importance } \\
\text { of the safety functions to be performed. }\end{array}$ & $\begin{array}{l}\text { Language } \\
\text { update }\end{array}$ \\
\hline 1.3 & $\begin{array}{l}\text { Fire Protection } \\
\text { Safety-related structures, systems, and components important to safety shall be designed and } \\
\text { located to minimize, consistent with other safety requirements, the probability and effect of fires } \\
\text { and explosions. Noncombustible and heat resistant materials shall be used wherever practical } \\
\text { throughout the unit, particularly in locations such as the containment and control room. Fire } \\
\text { detection and fighting systems of appropriate capacity and capability shall be provided and } \\
\text { designed to minimize the adverse effects of fires on structures, systems, and components important } \\
\text { to safety. Firefighting systems shall be designed to assure that their rupture or inadvertent } \\
\text { operation does not significantly impair the safety capability of these structures, systems, and } \\
\text { components. }\end{array}$ & $\begin{array}{l}\text { Language } \\
\text { update }\end{array}$ \\
\hline 1.4 & $\begin{array}{l}\text { Environmental Qualification } \\
\text { Safety-related structures, systems and components important to-safety shall be designed to } \\
\text { accommodate the effects of, and to be compatible with the environmental conditions associated } \\
\text { with normal operation, including anticipated operational occurrences, maintenance, testing, and } \\
\text { postulated accidents, including loss-of-coolant accidents. These structures, systems and } \\
\text { components shall be appropriately protected against dynamic effects, including such as the effects } \\
\text { of missiles, pipe whipping and discharging fluids that may-could result from equipment failures, } \\
\text { and from events and conditions outside the nuclear power unit. However, dynamic effects } \\
\text { associated with postulated pipe ruptures in nuclear power units may be excluded from the design } \\
\text { basis when analyses reviewed and approved by the Commission demonstrate that the probability of } \\
\text { fluid system piping rupture is extremely low under conditions consistent with the design basis for } \\
\text { the piping. }\end{array}$ & $\begin{array}{l}\text { Low pressure } \\
\text { system- } \\
\text { wording from } \\
\text { ANS } 54.1\end{array}$ \\
\hline 1.5 & $\begin{array}{l}\text { Sharing of Safety-Related Structures, Systems, and Components } \\
\text { Safety-related structures, systems, and components-impertant to safety shall not be shared among } \\
\text { nuclear power units, or reactors within a unit, unless it can be shown that such sharing will not } \\
\text { significantly impair their ability to perform their nuclear safety functions, including, in the event of } \\
\text { an accident in one unit or reactor, an orderly shutdown and cooldown of the remaining units or } \\
\text { reactors. }\end{array}$ & $\begin{array}{l}\text { Language } \\
\text { update }\end{array}$ \\
\hline
\end{tabular}


Table 2. Protection by multiple fission product barriers

\begin{tabular}{|c|c|c|}
\hline No. & Proposed FHR GDC & $\begin{array}{l}\text { Modification } \\
\text { basis }\end{array}$ \\
\hline 2.1 & $\begin{array}{l}\text { Reactor Design } \\
\text { The reactor core and associated coolant, control, and protection systems shall be designed with } \\
\text { appropriate margin to assure that specified acceptable fuel design limits are not exceeded during } \\
\text { any condition of normal operation, including the effects of anticipated operational occurrences. }\end{array}$ & \\
\hline 2.2 & $\begin{array}{l}\text { Reactor Inherent Protection } \\
\text { The reactor core and associated coolant systems shall be designed so that in the power operating } \\
\text { range the net effect of the prompt inherent nuclear feedback characteristics tends to compensate } \\
\text { for a rapid increase in reactivity. }\end{array}$ & \\
\hline 2.3 & $\begin{array}{l}\text { Suppression of Reactor Power Oscillations } \\
\text { The reactor core and associated coolant, control, and protection systems shall be designed to } \\
\text { assure that power oscillations which can result in conditions exceeding specified acceptable fuel } \\
\text { design limits are not possible or can be reliably and readily detected and suppressed. }\end{array}$ & \\
\hline 2.4 & $\begin{array}{l}\text { Instrumentation and Control } \\
\text { Instrumentation shall be provided to monitor variables and systems over their anticipated ranges } \\
\text { for normal operation, for anticipated operational occurrences, and for accident conditions as } \\
\text { appropriate to assure adequate safety, including those variables and systems that can affect the } \\
\text { fission process, the integrity of the reactor core, the reactor primary coolant pressure boundary, } \\
\text { and the containment and its associated systems. Appropriate controls shall be provided to } \\
\text { maintain these variables and systems within prescribed operating ranges. }\end{array}$ & $\begin{array}{l}\text { Low-pressure } \\
\text { system } \\
\text { employing } \\
\text { primary and } \\
\text { intermediate } \\
\text { coolant loops - } \\
\text { wording from } \\
\text { ANS 54.1 }\end{array}$ \\
\hline 2.5 & $\begin{array}{l}\text { Reactor Primary Coolant Pressure Boundary } \\
\text { The reactor primary coolant pressure boundary shall be designed, fabricated, erected, and tested } \\
\text { so as to have an extremely low probability of abnormal leakage, of rapidly propagating failure, } \\
\text { and of gross rupture. }\end{array}$ & $\begin{array}{l}\text { Low-pressure } \\
\text { system } \\
\text { employing } \\
\text { primary and } \\
\text { intermediate } \\
\text { coolant loops- } \\
\text { wording from } \\
\text { ANS 54.1 }\end{array}$ \\
\hline 2.6 & $\begin{array}{l}\text { Reactor Primary Coolant System Design } \\
\text { The reactor primary coolant system and associated auxiliary, control, and protection systems shall } \\
\text { be designed with sufficient margin to assure that the design conditions of the reactor primary } \\
\text { coolant pressure boundary are not exceeded during any condition of normal operation, including } \\
\text { anticipated operational occurrences. }\end{array}$ & $\begin{array}{l}\text { Low-pressure } \\
\text { system } \\
\text { employing } \\
\text { primary and } \\
\text { intermediate } \\
\text { coolant loops- } \\
\text { wording from } \\
\text { ANS 54.1 }\end{array}$ \\
\hline 2.7 & $\begin{array}{l}\text { Containment Design } \\
\text { Reactor containment and associated systems shall be provided to establish an essentially leak- } \\
\text { tight barrier against the uncontrolled release of radioactivity to the environment and to assure that } \\
\text { the containment design conditions important to safety are not exceeded for as long as postulated } \\
\text { accident conditions require. }\end{array}$ & \\
\hline
\end{tabular}


Table 2. Protection by multiple fission product barriers (continued)

\begin{tabular}{|c|c|c|}
\hline No. & Proposed FHR GDC & $\begin{array}{c}\text { Modification } \\
\text { basis }\end{array}$ \\
\hline 2.8 & 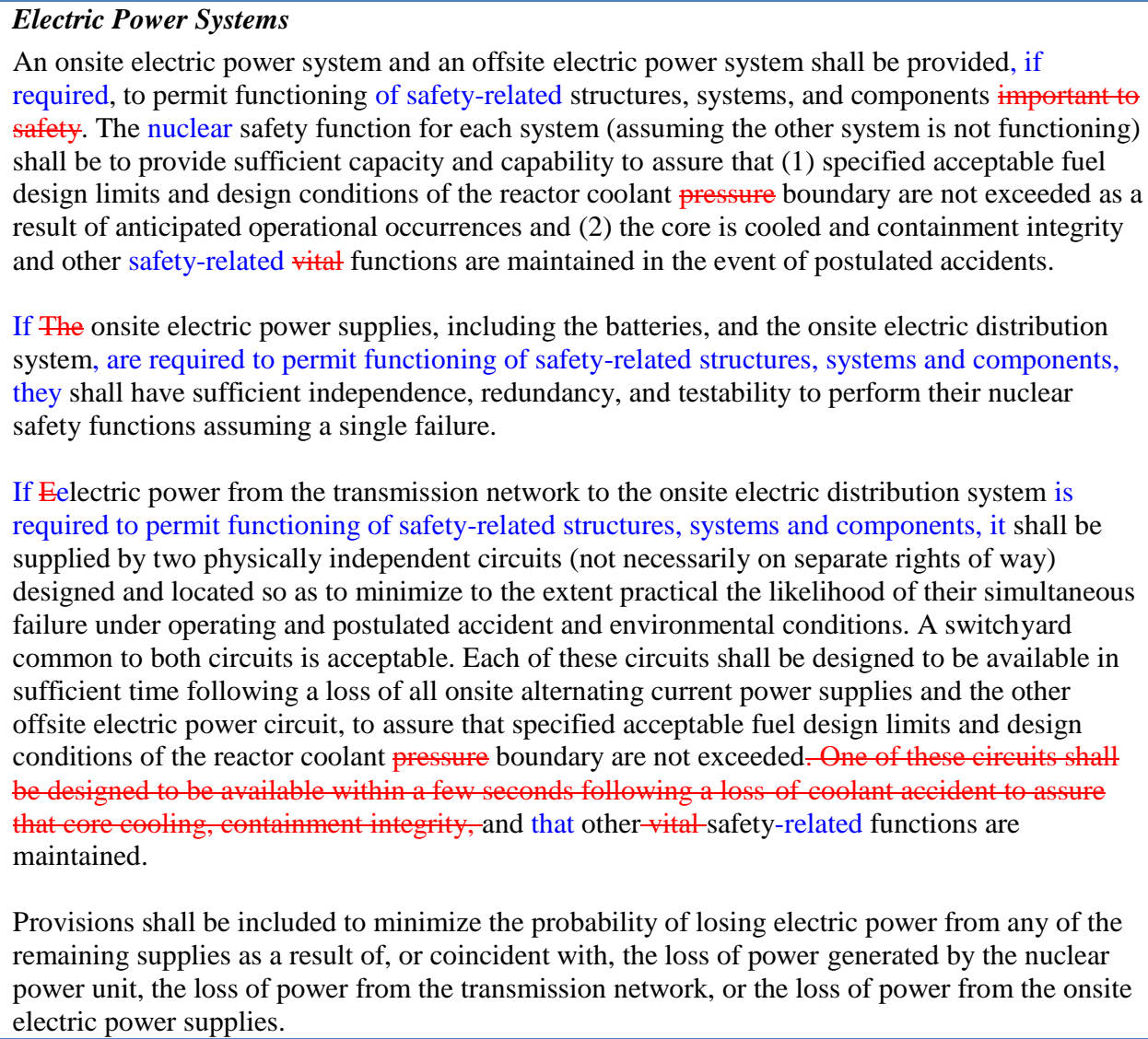 & $\begin{array}{l}\text { Low-pressure } \\
\text { system with } \\
\text { strong passive } \\
\text { safety } \\
\text { characteristics- } \\
\text { wording from } \\
\text { ANS } 54.1\end{array}$ \\
\hline 2.9 & $\begin{array}{l}\text { Inspection and Testing of Electric Power Systems } \\
\text { For station blackout, either (1) a means to prevent loss of core coolable geometry and spent fuel } \\
\text { coolable geometry shall be provided or (2) measures to mitigate such loss shall be provided. An } \\
\text { acceptable means to prevent loss of core coolable geometry and spent fuel coolable geometry is to } \\
\text { assure that the core is shut down and cooled, the spent fuel is cooled, and containment integrity is } \\
\text { maintained in the event of a station blackout of a specified duration. Consideration shall be given } \\
\text { to the effect of station blackout on plant environment (e.g., cell temperatures), and to providing } \\
\text { adequate instrumentation to monitor plant status for this event. } \\
\text { Safety-related electric power systems impertant to safety shall be designed to permit appropriate } \\
\text { periodic inspection and testing of important areas and features, such as wiring, insulation, } \\
\text { connections, and switchboards, to assess the continuity of the systems and the condition of their } \\
\text { components. The systems shall be designed with a capability to test periodically (1) the } \\
\text { operability and functional performance of the components of the systems, such as onsite power } \\
\text { sources, relays, switches, and buses, and (2) the operability of the systems as a whole and, under } \\
\text { conditions as close to design as practical, the full operational sequence that brings the systems } \\
\text { into operation, including operation of applicable portions of the protection system, and the } \\
\text { transfer of power among the nuclear power unit, the offsite power system, and the onsite power } \\
\text { system. }\end{array}$ & $\begin{array}{l}\text { Low-pressure } \\
\text { system with } \\
\text { strong passive } \\
\text { safety } \\
\text { characteristics- } \\
\text { wording from } \\
\text { ANS 54.1 }\end{array}$ \\
\hline
\end{tabular}


Table 2. Protection by multiple fission product barriers (continued)

\begin{tabular}{|c|c|c|}
\hline No. & Proposed FHR GDC & $\begin{array}{l}\text { Modification } \\
\text { basis }\end{array}$ \\
\hline 2.10 & 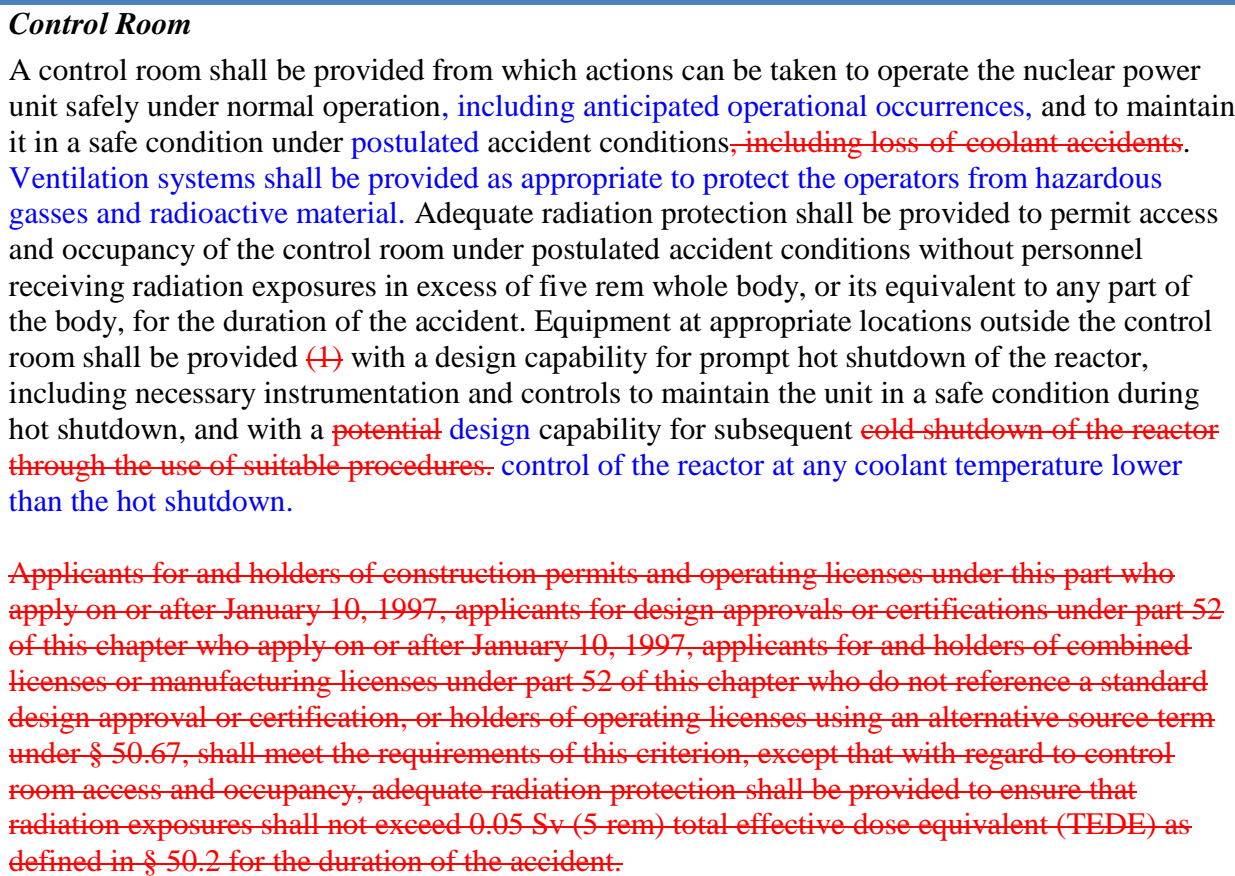 & $\begin{array}{l}\text { Cold shutdown } \\
\text { is not } \\
\text { applicable- } \\
\text { wording } \\
\text { partially from } \\
\text { ANS } 54.1\end{array}$ \\
\hline
\end{tabular}

Table 3. Protection and reactivity control systems

\begin{tabular}{|c|l|l|}
\hline No. & \multicolumn{2}{|c|}{$\begin{array}{l}\text { Podification } \\
\text { basis }\end{array}$} \\
\hline 3.1 & $\begin{array}{l}\text { Protection System Functions } \\
\text { The protection system shall be designed (1) to initiate automatically the operation of appropriate } \\
\text { systems including the reactivity control systems, to assure that specified acceptable fuel design } \\
\text { operational limits, such as reactor vessel temperature, are not exceeded as a result of anticipated } \\
\text { operational occurrences and (2) to sense accident conditions and to initiate the operation of } \\
\text { systems and components important to safety. }\end{array}$ & $\begin{array}{l}\text { Reactor vessel } \\
\text { not fuel is most } \\
\text { componente }\end{array}$ \\
\hline 3.2 & $\begin{array}{l}\text { Protection System Reliability and Testability } \\
\text { The protection system shall be designed for high functional reliability and in-service testability } \\
\text { commensurate with the safety functions to be performed. Redundancy and independence } \\
\text { designed into the protection system shall be sufficient to assure that (1) no single failure results in } \\
\text { loss of the protection function and (2) removal from service of any component or channel does } \\
\text { not result in loss of the required minimum redundancy unless the acceptable reliability of } \\
\text { operation of the protection system can be otherwise demonstrated. The protection system shall be } \\
\text { designed to permit periodic testing of its functioning when the reactor is in operation, including a } \\
\text { capability to test channels independently to determine failures and losses of redundancy that may } \\
\text { have occurred. }\end{array}$ & $\begin{array}{l}\text { Protection System Independence } \\
\text { The protection system shall be designed to assure that the effects of natural phenomena, and of } \\
\text { normal operating, maintenance, testing, and postulated accident conditions on redundant channels } \\
\text { do not result in loss of the protection function, or shall be demonstrated to be acceptable on some } \\
\text { other defined basis. Design techniques, such as functional diversity or diversity in component } \\
\text { design and principles of operation, shall be used to the extent practical to prevent loss of the } \\
\text { protection function. }\end{array}$ \\
\hline 3.3 & \\
\hline
\end{tabular}


Table 3. Protection and reactivity control systems (continued)

\begin{tabular}{|c|c|c|}
\hline No. & Proposed FHR GDC & $\begin{array}{c}\text { Modification } \\
\text { basis }\end{array}$ \\
\hline 3.4 & $\begin{array}{l}\text { Protection System Failure Modes } \\
\text { The protection system shall be designed to fail into a safe state or into a state demonstrated to be } \\
\text { acceptable on some other defined basis if conditions such as disconnection of the system, loss of } \\
\text { energy (e.g., electric power, instrument air), or postulated adverse environments (e.g., extreme } \\
\text { heat or cold, fire, pressure, steam, water, and radiation) are experienced. }\end{array}$ & $\begin{array}{l}\text { Removed } \\
\text { LWR-specific } \\
\text { description. }\end{array}$ \\
\hline 3.5 & $\begin{array}{l}\text { Separation of Protection and Control Systems } \\
\text { The protection system shall be separated from control systems to the extent that failure of any } \\
\text { single control system component or channel, or failure or removal from service of any single } \\
\text { protection system component or channel which is common to the control and protection systems } \\
\text { leaves intact a system satisfying all reliability, redundancy, and independence requirements of the } \\
\text { protection system. Interconnection of the protection and control systems shall be limited so as to } \\
\text { assure that safety is not significantly impaired. }\end{array}$ & \\
\hline 3.6 & $\begin{array}{l}\text { Protection System Requirements for Reactivity Control Malfunctions } \\
\text { The protection system shall be designed to assure that specified operational fueldesign-limits, } \\
\text { such as reactor vessel temperature, are not exceeded for any single malfunction of the reactivity } \\
\text { control systems, such as accidental withdrawal (not ejection or dropout) of control rods. }\end{array}$ & $\begin{array}{l}\text { Switched most } \\
\text { vulnerable } \\
\text { component call } \\
\text { out from fuel to } \\
\text { reactor vessel. }\end{array}$ \\
\hline 3.7 & $\begin{array}{l}\text { Reactivity Control System Redundancy and Capability } \\
\text { Two independent means of reactivity control systems of different design principles shall be } \\
\text { provided. Suitable independence and diversity shall be provided to assure adequate protection } \\
\text { against common cause failures. Each of these means shall be capable of performing its safety } \\
\text { function with a single active failure. One of the systems means shall use control rods elements } \\
\text { (e.g., rods, drums), preferably including a positive means for inserting the rods, and to move the } \\
\text { elements to reduce the reactivity. One of the means shall be capable of reliably controlling } \\
\text { reactivity changes to assure that under conditions of normal operation, including anticipated } \\
\text { operational occurrences, and with appropriate margin for malfunctions such as stuck rods } \\
\text { elements, specified acceptable fuel design operational limits, such as reactor vessel temperature, } \\
\text { are not exceeded. The second reactivity control system-One of the means shall be capable of } \\
\text { reliably controlling the rate of reactivity changes resulting from planned, normal power changes } \\
\text { (including xenon burnout) to assure acceptable fuel design limits-specified operational limits are } \\
\text { not exceeded. One of the systems means shall be capable of holding the reactor core subcritical } \\
\text { under cold conditions temperatures below hot shutdown. }\end{array}$ & $\begin{array}{l}\text { Updated } \\
\text { language } \\
\text { following ANS } \\
54.1 \text { to remove } \\
\text { LWR specific } \\
\text { terminology. }\end{array}$ \\
\hline 3.8 & $\begin{array}{l}\text { Combined Reactivity Control Systems Capability } \\
\text { The reactivity control systems shall be designed to have a combined capability, in conjunction } \\
\text { with poison addition, by the emergency core coeling system, of reliably controlling reactivity } \\
\text { changes to assure that under postulated accident conditions and with appropriate margin for stuck } \\
\text { rods the capability to cool the core is maintained. }\end{array}$ & $\begin{array}{l}\text { Removed } \\
\text { LWR-specific } \\
\text { emergency core } \\
\text { cooling system } \\
\text { reference. }\end{array}$ \\
\hline 3.9 & $\begin{array}{l}\text { Reactivity Limits } \\
\text { The reactivity control systems shall be designed with appropriate limits on the potential amount } \\
\text { and rate of reactivity increase to assure that the effects of postulated reactivity accidents can } \\
\text { neither (1) result in damage to the reactor coolant pressure boundary greater than limited local } \\
\text { yielding, nor (2) sufficiently disturb the core, its support structures or other reactor vessel } \\
\text { internals to impair significantly the capability to cool the core. These postulated reactivity } \\
\text { accidents shall include consideration of rod ejection (unless prevented by positive means), rod } \\
\text { drepeut, steam line rupture, conditions such as accidental withdrawal of control elements (e.g., } \\
\text { rods), changes in reactor coolant temperature and pressure, and cold water coolant addition. }\end{array}$ & $\begin{array}{l}\text { Removed high- } \\
\text { pressure system } \\
\text { references } \\
\text { following ANS } \\
54.1\end{array}$ \\
\hline
\end{tabular}


Table 3. Protection and reactivity control systems (continued)

\begin{tabular}{|c|c|c|}
\hline No. & Proposed FHR GDC & $\begin{array}{l}\text { Modification } \\
\text { basis }\end{array}$ \\
\hline 3.10 & $\begin{array}{l}\text { Protection Against Anticipated Operational Occurrences. } \\
\text { The protection and reactivity control systems shall be designed to assure an extremely high } \\
\text { probability of accomplishing their safety functions in the event of anticipated operational } \\
\text { occurrences. }\end{array}$ & \\
\hline 3.11 & $\begin{array}{l}\text { Protection Against Anticipated Transients Without Scram } \\
\text { For anticipated transients without scram, either (1) a means to prevent loss of core coolable } \\
\text { geometry violation of primary coolant boundary component design limits shall be provided or (2) } \\
\text { measures to mitigate such loss violation shall be provided. Acceptable means to prevent loss of } \\
\text { eөre coølable geometry violation of primary coolant boundary component design limits include: } \\
\text { (1) provide an acceptably high-reliability reactivity control system with features such as inherent } \\
\text { actuation or (2) provide inherent reactivity feedbacks so that anticipated transients without scram } \\
\text { do not result in aloss of cere coølable geometry violation of vessel design limits. }\end{array}$ & $\begin{array}{l}\text { Not in } \\
\text { Appendix A- } \\
\text { comparison } \\
\text { against ANS } \\
54.1 \text { revised to } \\
\text { reflect most } \\
\text { vulnerable FHR } \\
\text { component. }\end{array}$ \\
\hline
\end{tabular}

Table 4. Fluid systems

\begin{tabular}{|c|c|c|}
\hline No. & Proposed FHR GDC & $\begin{array}{l}\text { Modification } \\
\text { basis }\end{array}$ \\
\hline 4.1 & $\begin{array}{l}\text { Quality of Reactor Coolant Presstre Boundary } \\
\text { The reactor vessel and other Ecomponents which are part of the reactor coolant pressure } \\
\text { boundary shall be designed, fabricated, erected, and tested to the highest quality standards } \\
\text { practical. Means shall be provided for detecting and, to the extent practical, identifying the } \\
\text { tocation of the source of reactor coolant leakage. }\end{array}$ & $\begin{array}{l}\text { Updated wording } \\
\text { and revised to } \\
\text { reflect the FHR } \\
\text { low pressure and } \\
\text { coolant leakage } \\
\text { moved to } 4.3- \\
\text { similar to ANS } \\
54.1\end{array}$ \\
\hline 4.2 & $\begin{array}{l}\text { Fracture Prevention of Reactor Coolant Pressure Boundary } \\
\text { The reactor coolant pressure boundary and those parts of other coolant boundaries that use the } \\
\text { leak before break principle to define design basis leaks shall be designed with sufficient margin } \\
\text { to assure that when stressed under normal operatingons, including anticipated operational } \\
\text { occurrences, maintenance, testing, and postulated accident conditions (1) the boundary behaves } \\
\text { in a nonbrittle manner and (2) the probability of rapidly propagating fracture is minimized. The } \\
\text { design shall reflect consideration of service temperatures, service degradation of material } \\
\text { properties, creep, fatigue, stress rupture, and other conditions of the boundary material under } \\
\text { normal operatingon, including anticipated operational occurrences, maintenance, testing, and } \\
\text { postulated accident conditions and the uncertainties in determining (1) material properties, (2) } \\
\text { the effects of high-temperature, coolant chemistry, and irradiation on material properties, (3) } \\
\text { residual, steady state and transient stresses, and (4) size of flaws. }\end{array}$ & $\begin{array}{l}\text { Updated wording } \\
\text { and revised to } \\
\text { reflect the FHR } \\
\text { low pressure- } \\
\text { similar to ANS } \\
54.1\end{array}$ \\
\hline 4.3 & $\begin{array}{l}\text { Inspection and Surveillance of Reactor Coolant Pressure Boundary } \\
\text { Components which are part of the reactor coolant pressure boundary shall be designed to } \\
\text { permit (1) periodic inspection and surveillance testing ef important areas and features to assess } \\
\text { their structural and leaktight integrity-in accordance with the ASME Boiler and Pressure Vessel } \\
\text { Code Section XI, Division 3, as applicable, and (2) an appropriate material surveillance } \\
\text { program for the reactor pressure vessel. Means shall be provided for detecting and, to the } \\
\text { extent practical, locating the source of reactor coolant leakage. }\end{array}$ & $\begin{array}{l}\text { Revised to reflect } \\
\text { the FHR low } \\
\text { pressure-similar } \\
\text { to ANS } 54.1\end{array}$ \\
\hline
\end{tabular}


Table 4. Fluid systems (continued)

\begin{tabular}{|c|c|c|}
\hline No. & Proposed FHR GDC & $\begin{array}{l}\text { Modification } \\
\text { basis }\end{array}$ \\
\hline 4.4 & $\begin{array}{l}\text { Reactor Coolant Makeup-Adequate Reactor Coolant Inventory } \\
\text { A system to supply reactor coolant makeup for protection against small breaks in the reactor } \\
\text { coolant pressure boundary shall be provided. The system safety function shall be to assure that } \\
\text { specified acceptable fuel design limits are not exceeded as a result of reactor coolant loss due to } \\
\text { leakage from the reactor coolant pressure boundary and rupture of small piping or other small } \\
\text { components which are part of the boundary. The system shall be designed to assure that for onsite } \\
\text { electric power system operation (assuming offsite power is not available) and for offsite electric } \\
\text { power system operation (assuming onsite power is not available) the system safety function can } \\
\text { be accomplished using the piping, pumps, and valves used to maintain coolant inventory during } \\
\text { normal reactor operation. } \\
\text { The reactor coolant boundary and associated components, control and protection systems shall be } \\
\text { designed to limit loss of reactor coolant so that an inventory adequate to perform the safety } \\
\text { function of the reactor residual heat removal system is maintained under normal operation, } \\
\text { including anticipated operational occurrences, and postulated accident conditions, assuming a } \\
\text { failure of a single active component. } \\
\text { Instrumentation shall be provided to monitor the level of coolant inventory in the reactor vessel. } \\
\text { The instrumentation shall be designed with the capability to permit appropriate periodic } \\
\text { inspection and testing. }\end{array}$ & $\begin{array}{l}\text { Revised to } \\
\text { reflect different } \\
\text { safety criteria } \\
\text { for FHR. } \\
\text { Revision is } \\
\text { based on ANS } \\
54.1 \text { clause } \\
5(d) 1\end{array}$ \\
\hline \multirow[t]{2}{*}{4.5} & $\begin{array}{l}\text { Residual Heat Removal } \\
\text { A system to remove residual heat shall be provided. The system safety function shall be to } \\
\text { transfer fission product decay heat and other residual heat from the reactor core at a rate such that } \\
\text { specified acceptable fuel design limits and the design conditions of the reactor coolant pressure } \\
\text { boundary are not exceeded. A reactor residual heat removal system shall include means to } \\
\text { reliably transfer reactor residual heat to an ultimate heat sink under shutdown conditions } \\
\text { following normal operations, anticipated operational occurrences, or postulated accidents, such } \\
\text { that appropriate fuel design limits and the design conditions of the reactor coolant boundary are } \\
\text { not exceeded. Sufficient temperature margin shall be maintained above the freezing point of the } \\
\text { containment heat removal system fluid to assure system operability. } \\
\text { Suitable redundancy, independence and diversity in components and features shall be provided to } \\
\text { assure adequate protection against common cause failures and to assure that for onsite electric } \\
\text { power system operation (assuming offsite power is not available) and for offsite electric power } \\
\text { system operation (assuming onsite power is not available) the system safety function can be } \\
\text { accomplished, assuming a single failure. } \\
\text { A passive boundary shall separate reactor coolant from the working fluid of the reactor residual } \\
\text { heat removal system. Where a single barrier separates the reactor coolant from the working fluid } \\
\text { of the reactor residual heat removal system, a pressure differential shall be maintained such that } \\
\text { any leakage would flow from the reactor residual heat removal system to the reactor coolant } \\
\text { system unless other provisions can be shown to be acceptable on some defined basis. } \\
\text { Consideration shall be given to providing adequate instrumentation to monitor plant status } \\
\text { following anticipated operational occurrences or postulated accidents. }\end{array}$ & $\begin{array}{l}\text { Revised } \\
\text { reflecting } \\
\text { passive heat } \\
\text { rejection } \\
\text { similar to ANS } \\
54.1 \text {. Added } \\
\text { requirement to } \\
\text { maintain } \\
\text { cooling fluid } \\
\text { above freezing } \\
\text { point. Coolant } \\
\text { material } \\
\text { compatibility } \\
\text { and loss of core } \\
\text { coolable } \\
\text { geometry are } \\
\text { not FHR major } \\
\text { concerns, so } \\
\text { sodium } \\
\text { language is not } \\
\text { fully } \\
\text { applicable. }\end{array}$ \\
\hline & $\begin{array}{l}\text { Emergency Core Cooling } \\
\text { A system to provide abundant emergency core cooling shall be provided. The system safety } \\
\text { function shall be to transfer heat from the reactor core following any loss of reactor coolant at a } \\
\text { rate such that (1) fuel and clad damage that could interfere with continued effective core cooling } \\
\text { is prevented and (2) clad metal-water reaction is limited to negligible amounts. } \\
\text { Suitable redundancy in components and features, and suitable interconnections, leak detection, } \\
\text { isolation, and containment capabilities shall be provided to assure that for onsite electric power } \\
\text { system operation (assuming offsite power is not available) and for offsite electric power system } \\
\text { operation (assuming onsite power is not available) the system safety function can be } \\
\text { accomplished, assuming a single failure. }\end{array}$ & $\begin{array}{l}\text { Deleted not } \\
\text { applicable. } \\
\text { Follows ANS } \\
54.1\end{array}$ \\
\hline
\end{tabular}


Table 4. Fluid systems (continued)

\begin{tabular}{|c|c|c|}
\hline No. & Proposed FHR GDC & $\begin{array}{l}\text { Modification } \\
\text { basis }\end{array}$ \\
\hline \multirow[t]{2}{*}{4.6} & $\begin{array}{l}\text { Inspection and Testing of Emergency Core Cooling the Residual Heat Removal System } \\
\text { The emergency core cooling reactor residual heat removal system shall be designed to permit } \\
\text { appropriate periodic inspection of important components, such as spray rings in the reactor } \\
\text { pressure vessel, water injection nozzles, heat exchangers and piping, to assure the integrity and } \\
\text { capability of the system. } \\
\text { The reactor residual heat removal system shall be designed to permit appropriate periodic } \\
\text { functional testing as applicable to assure: (1) the structural and leak-tight integrity of the } \\
\text { components, (2) the operability and the performance of any active components of the system, and } \\
\text { (3) the operability of the system as a whole and, under conditions as close to design as practical, } \\
\text { the performance of the full operational sequence that brings the system into operation for reactor } \\
\text { shutdown and following postulated accidents, including operation of applicable portions of the } \\
\text { protection system and any interfaces with the ultimate heat sink. } \\
\text { Passive systems shall be designed to permit performance demonstration, under conditions as close } \\
\text { to design as practical, to assure operability of the systems. }\end{array}$ & $\begin{array}{l}\text { Follows ANS } \\
54.1 \text { with } \\
\text { exception of } \\
\text { lack of } \\
\text { emergency } \\
\text { power sources } \\
\text { for FHRs. }\end{array}$ \\
\hline & $\begin{array}{l}\text { Festing of Emergency Core Cooling System } \\
\text { The emergency core cooling system shall be designed to permit appropriate periodic pressure and } \\
\text { functional testing to assure (1) the structural and leaktight integrity of its components, ( } 2 \text { ) the } \\
\text { operability and performance of the active components of the system, and ( } 3 \text { ) the operability of the } \\
\text { system as a whole and, under conditions as close to design as practical, the performance of the } \\
\text { full-operational sequence that brings the system into-peration, including operation of applicable } \\
\text { portions of the protection system, the transfer between normal and emergency power sources, and } \\
\text { the operation of the associated cooling water system. }\end{array}$ & $\begin{array}{l}\text { Not applicable } \\
\text { to FHRs- } \\
\text { testing of } \\
\text { residual heat } \\
\text { removal system } \\
\text { added to 4.6- } \\
\text { Inspection and } \\
\text { testing are } \\
\text { combined in } \\
\text { ANS 54.1. }\end{array}$ \\
\hline 4.7 & $\begin{array}{l}\text { Containment Heat Removal } \\
\text { A system to remove heat from the reactor containment shall be provided. The system safety } \\
\text { function shall be to maintain the containment temperature during and following normal operation, } \\
\text { including anticipated operational occurrences and postulated accidents reduce rapidly, consistent } \\
\text { with the functioning of other asseciated systems, the containment pressure and temperature } \\
\text { following any loss of coolant aceident and maintain them-at acceptably low levels. Suitable } \\
\text { redundancy in components and features, and suitable interconnections, leak detection, isolation, } \\
\text { and containment capabilities shall be provided to assure that for onsite electric power system } \\
\text { operation (assuming offsite power is not available) and for offsite electric power system operation } \\
\text { (assuming onsite power is not available) the system safety function can be accomplished, } \\
\text { assuming a single failure. }\end{array}$ & $\begin{array}{l}\text { FHRs do not } \\
\text { include means } \\
\text { to pressurize } \\
\text { containment. } \\
\text { Leak of a low- } \\
\text { pressure liquid } \\
\text { coolant will not } \\
\text { rapidly heat up } \\
\text { containment. }\end{array}$ \\
\hline 4.8 & $\begin{array}{l}\text { Inspection and Testing of Containment Heat Removal System } \\
\text { The containment heat removal system shall be designed to permit appropriate periodic inspection } \\
\text { of important components, such as the torus, sumps, spray nozzles, and piping to assure the } \\
\text { integrity and capability of the system. } \\
\text { The containment heat removal system shall be designed to permit appropriate periodic pressure } \\
\text { and functional testing to assure (1) the structural and leaktight integrity of its components, (2) the } \\
\text { operability and performance of the active components of the system, and (3) the operability of the } \\
\text { system as a whole, and under conditions as close to the design as practical the performance of the } \\
\text { full operational sequence that brings the system into operation, including operation of applicable } \\
\text { portions of the protection system, the transfer between normal and emergency power sources, and } \\
\text { any interfaces with the ultimate heat sink the operation of the associated cooling water system. }\end{array}$ & $\begin{array}{l}\text { Inspection and } \\
\text { testing } \\
\text { combined into a } \\
\text { single criteria } \\
\text { following ANS } \\
54.1 \text {. Reference } \\
\text { to emergency } \\
\text { power source } \\
\text { removed for } \\
\text { FHR. Water } \\
\text { reference } \\
\text { exchanged for } \\
\text { ultimate heat } \\
\text { sink as air is } \\
\text { likely for an } \\
\text { FHR. }\end{array}$ \\
\hline
\end{tabular}


Table 4. Fluid systems (continued)

\begin{tabular}{|c|c|c|}
\hline \multirow[t]{2}{*}{ No. } & Proposed FHR GDC & $\begin{array}{c}\text { Modification } \\
\text { basis }\end{array}$ \\
\hline & $\begin{array}{l}\text { Testing of Containment Heat Removal System. } \\
\text { The containment heat removal system shall be designed to permit appropriate periodic pressure } \\
\text { and functional testing to assure (1) the structural and leaktight integrity of its components, ( } 2 \text { ) the } \\
\text { operability and performance of the active components of the system, and ( } 3 \text { ) the operability of the } \\
\text { system as a whole, and under conditions as close to the design as practical the performance of the } \\
\text { full operational sequence that brings the system into operation, including operation of applicable } \\
\text { portions of the protection system, the transfer between normal and emergency power sources, and } \\
\text { the operation of the associated cooling water system. }\end{array}$ & $\begin{array}{l}\text { Combined into } \\
\text { previous } \\
\text { criteria. }\end{array}$ \\
\hline 4.9 & $\begin{array}{l}\text { Containment Atmosphere Cleanup Control } \\
\text { Systems to control fission products, hydrogen, oxygen, and other substances which may be } \\
\text { released into the reactor containment shall be provided as necessary to reduce, consistent with the } \\
\text { functioning of other associated systems, the concentration and quality of fission products released } \\
\text { to the environment following postulated accidents, and to control the concentration of hydrogen } \\
\text { or oxygen and other substances in the containment atmosphere following postulated accidents to } \\
\text { assure that containment integrity is maintained. } \\
\text { Each system shall have suitable redundancy in components and features, and suitable } \\
\text { interconnections, leak detection, isolation, and containment capabilities to assure that for onsite } \\
\text { electric power system operation (assuming offsite power is not available) and for offsite electric } \\
\text { power system operation (assuming onsite power is not available) its any safety function can be } \\
\text { accomplished, assuming a single failure. }\end{array}$ & $\begin{array}{l}\text { No safety-grade } \\
\text { electrical power } \\
\text { generally } \\
\text { required. }\end{array}$ \\
\hline \multirow[t]{3}{*}{4.10} & $\begin{array}{l}\text { Inspection and Testing of Containment Atmosphere Cleantp-Control Systems } \\
\text { The containment atmosphere eleanup control systems shall be designed to permit appropriate } \\
\text { periodic inspection of important components, such as filter frames, ducts, and piping to assure the } \\
\text { integrity and capability of the systems. } \\
\text { The containment atmosphere eleanup control systems shall be designed to permit appropriate } \\
\text { periodic pressure and functional testing to assure (1) the structural and leaktight integrity of its } \\
\text { components, (2) the operability and performance of the active components of the systems such as } \\
\text { fans, filters, dampers, pumps, and valves and (3) the operability of the systems as a whole and, } \\
\text { under conditions as close to design as practical, the performance of the full operational sequence } \\
\text { that brings the systems into operation, including operation of applicable portions of the protection } \\
\text { system, the transfer between normal and emergency power sources, and the operation of } \\
\text { associated systems. }\end{array}$ & $\begin{array}{l}\text { No safety } \\
\text { function for } \\
\text { postulated } \\
\text { accidents. } \\
\text { Inspection and } \\
\text { testing } \\
\text { combined into } \\
\text { single criteria } \\
\text { as per ANS } \\
54.1\end{array}$ \\
\hline & $\begin{array}{l}\text { Testing of containment Atmosphere Cleanup Systems } \\
\text { The containment atmosphere cleanup systems shall be designed to permit appropriate periodic } \\
\text { pressure and functional testing to assure (1) the structural and leaktight integrity of its } \\
\text { components, (2) the operability and performance of the active components of the systems such as } \\
\text { fans, filters, dampers, pumps, and valves and ( } 3 \text { ) the operability of the systems as a whole and, } \\
\text { under conditions as close to design as practical, the performance of the full operational sequence } \\
\text { that brings the systems into operation, including operation of applicable portions of the protection } \\
\text { system, the transfer between normal and emergency power sources, and the operation of } \\
\text { associated systems. }\end{array}$ & $\begin{array}{l}\text { Combined into } \\
\text { previous } \\
\text { criteria. }\end{array}$ \\
\hline & $\begin{array}{l}\text { Cooling Water } \\
\text { A system to transfer heat from structures, systems, and components important to safety, to an } \\
\text { ultimate heat sink shall be provided. The system safety function shall be to transfer the combined } \\
\text { heat load of these structures, systems, and components under normal operating and accident } \\
\text { conditions. } \\
\text { Suitable redundancy in components and features, and suitable interconnections, leak detection, } \\
\text { and isolation capabilities shall be provided to assure that for onsite electric power system } \\
\text { operation (assuming offsite power is not available) and for offsite electric power system operation } \\
\text { (assuming onsite power is not avilable) the system safety function can be accomplished, } \\
\text { assuming a single failure. }\end{array}$ & $\begin{array}{l}\text { The closest } \\
\text { analogy for an } \\
\text { FHR is to the } \\
\text { containment } \\
\text { heat removal } \\
\text { system } \\
\text { described in } \\
4.7 \text {. }\end{array}$ \\
\hline
\end{tabular}


Table 4. Fluid system (continued)

\begin{tabular}{|l|l|l|}
\hline No. & \multicolumn{2}{|c|}{$\begin{array}{l}\text { Proposed FHR GDC } \\
\text { basis }\end{array}$} \\
\hline & $\begin{array}{l}\text { Inspection of Cooling Water Systemt } \\
\text { The cooling water system shall be designed to permit appropriate periodic inspection of important } \\
\text { components, such as heat exchangers and piping, to assure the integrity and capability of the } \\
\text { system. }\end{array}$ & $\begin{array}{l}\text { The closest } \\
\text { analogy for an } \\
\text { FHR is to the } \\
\text { containment } \\
\text { heat removal } \\
\text { system } \\
\text { described in } \\
4.8 .\end{array}$ \\
\hline $\begin{array}{l}\text { Testing of Cooling Water Systemt } \\
\text { The cooling water system shall be designed to permit appropriate periodic pressure and functional } \\
\text { testing to assure (1) the structural and leaktight integrity of its components, (2) the operability and } \\
\text { the performance of the active components of the system, and (3) the operability of the system as a } \\
\text { whole and, under conditions as close to design as practical, the performance of the full } \\
\text { operational sequence that brings the system into operation for reactor shutdown and for loss-of- } \\
\text { coolant accidents, including operation of applicable portions of the protection system and the } \\
\text { transfer between normal and emergency power sources. }\end{array}$ & $\begin{array}{l}\text { The closest } \\
\text { analogy for an } \\
\text { containment } \\
\text { heat removal } \\
\text { system } \\
\text { described in } \\
4.8 .\end{array}$ \\
\hline
\end{tabular}

Table 5. Reactor containment

\begin{tabular}{|c|c|c|}
\hline No. & Proposed FHR GDC & $\begin{array}{c}\text { Modification } \\
\text { basis }\end{array}$ \\
\hline 5.1 & $\begin{array}{l}\text { Containment System Design Basis } \\
\text { The reactor containment structure, including access openings, penetrations, and the containment } \\
\text { heat removal system-shall be designed to limit the release of radioactivity so that the established } \\
\text { dose guidelines are not exceeded for postulated accidents. The system, including internal } \\
\text { structures, access openings and penetrations, shall be designed to meet its safety function with } \\
\text { margin to accommodate the calculated pressure and temperature conditions resulting from normal } \\
\text { operation, including anticipated operational occurrences, and postulated accidents, assuming } \\
\text { failure of a single active component. so that the containment structure and its internal } \\
\text { eompartments can accommodate, without exceeding the design leakage rate and with sufficient } \\
\text { margin, the calculated pressure and temperature conditions resulting from any loss-of-coolant } \\
\text { accident. This margin shall reflect consideration of (1) the effects of potential energy sources } \\
\text { which have not been included in the determination of the peak conditions, such as energy in steam } \\
\text { generators and as required by } \$ 50.44 \text { energy from metal-water and other chemical reactions that } \\
\text { may result from degradation but not total failure of emergency core cooling functioning heat in } \\
\text { released fission products and potential for hydrogen release from salt cleanup system, (2) the } \\
\text { limited experience and experimental data available for defining accident phenomena and } \\
\text { containment responses, and (3) the conservatism of the calculational model and input parameters. }\end{array}$ & $\begin{array}{l}\text { Used ANS } \\
54.1 \text { wording } \\
\text { modified to } \\
\text { exclude } \\
\text { sodium } \\
\text { chemical } \\
\text { reactions and } \\
\text { include salt } \\
\text { cleanup system } \\
\text { chemistry. }\end{array}$ \\
\hline 5.2 & $\begin{array}{l}\text { Fracture Prevention of Containment Pressure Boundary } \\
\text { The reactor containment boundary shall be designed with sufficient margin to assure that under } \\
\text { operating, maintenance, testing, and postulated accident conditions (1) its ferritie metallic } \\
\text { materials behave in a nonbrittle manner and (2) the probability of rapidly propagating fracture is } \\
\text { minimized. The design shall reflect consideration of service temperatures and other conditions of } \\
\text { the containment boundary material during operation, maintenance, testing, and postulated accident } \\
\text { conditions, and the uncertainties in determining (1) material properties, (2) residual, steady state, } \\
\text { and transient stresses, and (3) size of flaws. }\end{array}$ & $\begin{array}{l}\text { FHR } \\
\text { containment } \\
\text { may not be } \\
\text { ferritic but } \\
\text { may be subject } \\
\text { to neutron } \\
\text { embrittlement. }\end{array}$ \\
\hline 5.3 & $\begin{array}{l}\text { Capability for Containment Leakage Rate Testing } \\
\text { The reactor containment and other equipment, which may be subjected to containment test } \\
\text { conditions, shall be designed so that periodic integrated leakage rate testing can be conducted at } \\
\text { eentainment design pressure to verify the design leak rate. }\end{array}$ & $\begin{array}{l}\text { Followed ANS } \\
54.1 .\end{array}$ \\
\hline
\end{tabular}


Table 5. Reactor containment (continued)

\begin{tabular}{|c|c|c|}
\hline No. & Proposed FHR GDC & $\begin{array}{l}\text { Modification } \\
\text { basis }\end{array}$ \\
\hline 5.4 & $\begin{array}{l}\text { Provisions for Containment System Testing and Inspection } \\
\text { Any portions of Tthe reactor containment system relied upon to perform a safety function shall be } \\
\text { designed to permit (1) appropriate periodic inspection of all important areas, such as penetrations, } \\
\text { and (2) an appropriate surveillance program., and (3) The reactor containment system shall be } \\
\text { designed to permit periodic testing at containment design pressure of the leak-tightness of } \\
\text { penetrations which have resilient seals and expansion bellows. }\end{array}$ & $\begin{array}{l}\text { Followed ANS } \\
54.1 .\end{array}$ \\
\hline 5.5 & $\begin{array}{l}\text { Piping Systems Penetrating Containment } \\
\text { Piping systems penetrating primary reactor containment shall be provided with leak detection, } \\
\text { isolation, and containment capabilities having redundancy, reliability, and performance } \\
\text { eapabilities which reflect the importance to safety of isolating these piping systems as required to } \\
\text { perform the containment safety function. Steh Where isolation valves are required, the piping } \\
\text { systems shall be designed with a capability to test periodically the operability of the isolation } \\
\text { valves and associated apparatus and to determine if valve leakage is within acceptable limits. }\end{array}$ & $\begin{array}{l}\text { Followed ANS } \\
54.1 .\end{array}$ \\
\hline 5.6 & $\begin{array}{l}\text { Reactor Coolant Pressure Boundary Penetrating Containment } \\
\text { Each line that is part of or directly connected to the reactor coolant pressure boundary and that } \\
\text { penetrates primary reactor containment shall be provided with containment isolation valves as } \\
\text { follows, unless it can be demonstrated that the containment isolation provisions for a specific class } \\
\text { of lines, such as instrument lines, are acceptable on some other defined basis: } \\
\text { (1) One locked closed isolation valve inside and one locked closed isolation valve outside } \\
\text { containment; or } \\
\text { (2) One automatic isolation valve inside and one locked closed isolation valve outside } \\
\text { containment; or } \\
\text { (3) One locked closed isolation valve inside and one automatic isolation valve outside } \\
\text { containment. A simple check valve may shall not be used as the automatic isolation valve outside } \\
\text { containment; or } \\
\text { (4) One automatic isolation valve inside and one automatic isolation valve outside containment. } \\
\text { A simple check valve may shall not be used as the automatic isolation valve outside containment. } \\
\text { Isolation valves outside containment shall be located as close to containment as practical and upon } \\
\text { loss of actuating power, automatic isolation valves shall be designed to take the position that } \\
\text { provides greater nuclear safety. } \\
\text { Other appropriate requirements to minimize the probability or consequences of an accidental } \\
\text { rupture of these lines or of lines connected to them shall be provided as necessary to assure } \\
\text { adequate safety. Determination of the appropriateness of these requirements, such as higher } \\
\text { quality in design, fabrication, and testing, additional provisions for inservice inspection, protection } \\
\text { against more severe natural phenomena, and additional isolation valves and containment, shall } \\
\text { include consideration of the population density, use characteristics, and physical characteristics of } \\
\text { the site environs. }\end{array}$ & $\begin{array}{l}\text { Followed ANS } \\
54.1 .\end{array}$ \\
\hline
\end{tabular}


Table 5. Reactor containment (continued)

\begin{tabular}{|c|c|c|}
\hline No. & Proposed FHR GDC & $\begin{array}{l}\text { Modification } \\
\text { basis }\end{array}$ \\
\hline 5.7 & $\begin{array}{l}\text { Primary Containment Isolation } \\
\text { Each line that connects directly to the containment atmosphere and penetrates primary reactor } \\
\text { containment shall be provided with containment isolation valves as follows, unless it can be } \\
\text { demonstrated that the containment isolation provisions for a specific class of lines, such as } \\
\text { instrument lines, are acceptable on some other defined basis: } \\
\text { (1) One locked closed isolation valve inside and one locked closed isolation valve outside } \\
\text { containment; or } \\
\text { (2) One automatic isolation valve inside and one locked closed isolation valve outside } \\
\text { containment; or } \\
\text { (3) One locked closed isolation valve inside and one automatic isolation valve outside } \\
\text { containment. A simple check valve may shall not be used as the automatic isolation valve outside } \\
\text { containment; or } \\
\text { (4) One automatic isolation valve inside and one automatic isolation valve outside containment. } \\
\text { A simple check valve may shall not be used as the automatic isolation valve outside containment. } \\
\text { Isolation valves outside containment shall be located as close to the containment as practical and } \\
\text { upon loss of actuating power, automatic isolation valves shall be designed to take the position that } \\
\text { provides greater nuclear safety. }\end{array}$ & $\begin{array}{l}\text { Followed ANS } \\
54.1 .\end{array}$ \\
\hline 5.8 & $\begin{array}{l}\text { Closed System Isolation Valves } \\
\text { Each line that penetrates primary reactor containment and is neither part of nor directly connected } \\
\text { to the reactor coolant presstre boundary nor connected directly to the containment atmosphere } \\
\text { shall have at least one containment isolation valve unless it can be demonstrated that containment } \\
\text { isolation provisions for a specific class of lines are acceptable on some other defined basis. The } \\
\text { isolation valve, if required, which shall be either automatic, or locked closed, or capable of remote } \\
\text { manual operation. This valve shall be outside containment and located as close to the containment } \\
\text { as practical. A simple check valve may shall not be used as the automatic isolation valve. }\end{array}$ & $\begin{array}{l}\text { Followed ANS } \\
54.1 .\end{array}$ \\
\hline
\end{tabular}

Table 6. Fuel and radioactivity control

\begin{tabular}{|c|l|l|}
\hline No. & \multicolumn{1}{|c|}{ Proposed FHR GDC } \\
\hline 6.1 & $\begin{array}{l}\text { Control of Releases of Radioactive Materials to the Environment } \\
\text { The nuclear power unit design shall include means to control suitably the release of radioactive } \\
\text { materials in gaseous and liquid effluents and to handle radioactive solid wastes produced during } \\
\text { normal reactor operation, including anticipated operational occurrences. Sufficient holdup capacity } \\
\text { shall be provided for retention of gaseous and liquid effluents containing radioactive materials, } \\
\text { particularly where unfavorable site environmental conditions can be expected to impose unusual } \\
\text { operational limitations upon the release of such effluents to the environment. }\end{array}$ & $\begin{array}{l}\text { Fuel Storage and Handling and Radioactivity Control } \\
\text { The fuel storage and handling, radioactive waste, and other systems which may contain } \\
\text { radioactivity shall be designed to assure adequate safety under normal and postulated accident } \\
\text { conditions. These systems shall be designed (1) with a capability to permit appropriate periodic } \\
\text { inspection and testing of components important to safety, (2) with suitable shielding for radiation } \\
\text { protection, (3) with appropriate containment, confinement, and filtering systems, (4) with a } \\
\text { residual heat removal capability having reliability and testability that reflects the importance to } \\
\text { safety of decay heat and other residual heat removal, and (5) to prevent significant reduction in fuel } \\
\text { storage coolant inventory under accident conditions. }\end{array}$ \\
\hline 6.2 & $\begin{array}{l}\text { Prevention of Criticality in Fuel Storage and Handling } \\
\text { Criticality in the fuel storage and handling system shall be prevented by physical systems or } \\
\text { processes, preferably by use of geometrically safe configurations. }\end{array}$ & \\
\hline 6
\end{tabular}


Table 6. Fuel and radioactivity control (continued)

\begin{tabular}{|c|l|c|}
\hline No. & \multicolumn{1}{c|}{ Proposed FHR GDC } & \multicolumn{1}{c|}{$\begin{array}{c}\text { Modification } \\
\text { basis }\end{array}$} \\
\hline 6.4 & $\begin{array}{l}\text { Monitoring Fuel and Waste Storage } \\
\text { Appropriate systems shall be provided in fuel storage and radioactive waste systems and associated } \\
\text { handling areas (1) to detect conditions that may result in loss of residual heat removal capability } \\
\text { and excessive radiation levels and (2) to initiate appropriate safety actions. }\end{array}$ & $\begin{array}{l}\text { Monitoring Radioactivity Releases } \\
\text { Means shall be provided for monitoring the reactor containment atmosphere, spaces containing } \\
\text { components for recirculation of loss-of-coolant accident fluids, effluent discharge paths, and the } \\
\text { plant environs for radioactivity that may be released from normal operations, including anticipated } \\
\text { operational occurrences, and from postulated accidents. }\end{array}$ \\
\hline \multicolumn{2}{|}{}
\end{tabular}

\section{PATH FORWARD TOWARDS A SAFETY STANDARD AND FHR LICENSING}

The GDC found in Section 6 are draft in nature since they represent the thinking of a small set of subject matter experts (SMEs). It is necessary to get broader input to the FHR GDC formulation process so as to represent all the stakeholders interested in FHR development. One process is to develop a consensus standard similar to the SFR ANS 54.1 standard mentioned above. The first step in this process is to ascertain interest in the development of such a standard. A meeting has been scheduled with the ANS standards group for that purpose.

In addition to FHR-specific GDC development, two other important steps are needed to examine the safety issues related to FHRs. One is to begin the formulation of FHR-specific Licensing Basis Events, which will be used to determine the Abnormal Operational Occurrences, Design Basis Events, and Beyond Design Basis Events. The second is to perform a safety technology gap analysis [similar to a phenomenon identification and ranking table (PIRT)] to determine future R\&D needs related to FHR safety. A similar analysis has just been completed for the SFR program.

FHRs, however, are at a lower level of maturity than SFRs, and both materials and early phase component validation tasks are already apparent in developing sufficient understanding to present a strong safety case. For example, the near core structural components for an FHR will almost certainly be composed of a ceramic composite. Neither carbon-carbon nor silicon carbide-silicon carbide composites are currently qualified for nuclear power plant use. Additionally, tritium will be generated in the primary coolant by an FHR, and tritium will permeate through metals at high temperature. Means to separate the tritium from the primary coolant and isolate it from the environment need to be developed to enable normal operation. Also, no fluoride-salt-compatible alloy is currently qualified for use in a hightemperature reactor without active redox and electronegative impurity control. As the DRACS heat exchanger and the primary-to-intermediate heat exchangers are part of the primary coolant boundary and require a monolithic salt-compatible alloy, advanced alloy development and qualification is an already known technology development requirement. 


\section{REFERENCES}

1. Idaho National Laboratory, NGNP Fuel Qualification White Paper, INL/EXT-10-17686 Rev 0, July 2010 .

2. International Atomic Energy Agency, Fuel Performance and Fission Product Behaviour in Gas Cooled Reactors, IAEA-TECDOC-978, November 1997.

3. Commissioner G. Apostolakis, M. Cunningham, C. Lui, G. Pangburn, W. Reckley, A Proposed Risk Management Regulatory Framework, NUREG-2150, April 2012.

4. NUREG-800, Standard Review Plan for the Review of Safety Analysis Reports for Nuclear Power Plants: LWR Edition.

5. M. Drouin, Feasibility Study for a Risk-Informed and Performance-Based Regulatory Structure for Future Plant Licensing, Volumes 1 and 2, NUREG-1860, December 2007.

6. Nuclear Safety Criteria and Design Process for Liquid-Sodium-Cooled-Reactor Nuclear Power Plants, ANS Draft Standard 54.1, October 2011 version.

7. NGNP Licensing Plan, Project No. 29980, Document ID PLN-3202, Revision ID 0, Idaho National Laboratory, June 26, 2009. 
APPENDIX-ANS 54.1 SCOPE AND PURPOSE 



\section{Nuclear Safety Criteria and Design Process for Liquid-Sodium Metal-Cooled-Reactor Nuclear Power Plants}

\section{Scope}

This standard establishes the nuclear safety criteria, functional performance requirements, and design requirements for liquid-metal sodium-cooled nuclear power plants. The document uses performancebased, risk-informed PRA criteria wherever possible. It also describes the design process to be followed to establish those criteria and perform structures, systems, and component classifications.

\section{Purpose}

This standard defines safety objectives, general design criteria, selection of LBEs, and classification of SSCs that can be used by designers and regulators of sodium-cooled reactor nuclear power plants. It is intended to serve a purpose similar to the GDCs promulgated by the NRC for LWRs in 10 CFR 50, Appendix A. It is expected that this standard will be useful to the NRC as it develops the regulatory guidance for sodium-cooled reactor nuclear power plants.

The overarching purpose of this standard is to define criteria to be satisfied for providing assurance that sodium-cooled reactor nuclear power plants are designed so that they can be operated with acceptable risk to public health and safety and to the environment. This purpose is achieved through the identification of applicable safety requirements from the NRC, industrial codes and standards, and other published guidance and professional engineering practices. It is also the purpose of this standard to define requirements for the acceptable use of probabilistic risk information in support of design decisions (i.e., risk-informed design criteria). 